\title{
Bitmeyen Bir İskân Tartışması: Galata'da Yeni Valide ve Arap Camileri Etrafında Katolik - Müslüman Çekişmesi (1693-1713)*
}

\section{An Endless Conflict of Settlement: Catholic - Muslim Rivalry around New Valide and Arab Mosques in Galata (1693-1713)}

\author{
Kenan Yıldı' ${ }^{1}$ (1)
}

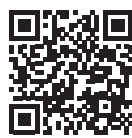

*italyanca kaynakları kullanmamda yardımcı olan Tommaso Stefini'ye, makale ile ilgili değerli görüșlerini paylaşan ve destek olan Vanessa de Obaldia ve Emrah Safa Gürkan'a teșekkür ederim.

'Sorumlu yazar/Corresponding author: Kenan Yıldız (Doç. Dr.),

İstanbul Medeniyet Üniversitesi, Edebiyat Fakültesi, Bilgi Ve Belge Yönetimi Bölümü, İstanbul, Türkiye

E-posta: yildizk@gmail.com

ORCID: 0000-0003-0781-3576

Başvuru/Submitted: 27.06.2020

Revizyon Talebi/Revision Requested: 16.07.2020

Son Revizyon/Last Revision Received: 29.07.2020

Kabul/Accepted: 01.08 .2020

Online Yayın/Published Online: 00.00 .0000

Atıf/Citation: Yildiz, Kenan, "Bitmeyen Bir İskân Tartışması: Galata'da Yeni Valide ve Arap Camileri Etrafında Katolik - Müslüman Çekişmesi (1693-1713)", Güneydoğu Avrupa Araştırmaları Dergisi, 34 (2020), s. 93-117. https://doi.org/10.26650/gaad.20213404

\section{öz}

Galata'nın en büyük kiliselerinden biri olan San Domeniko Kilisesi, Fatih tarafından 1475 dolaylarında camiye dönüştürüldü. Çevresine İspanya'dan gelen Müslümanların iskân edilmesi sonucu bu mabet daha sonraları Arap Camii olarak anılmaya başladı. Galata'nın en önemli Katolik kilisesi olan ve Arap Camii'ne çok yakın bir yerde bulunan San Françesko Kilisesi'nin yerine de 1696 yangını sonrasında Gülnuş Valide Sultan tarafından cami (Yeni Cami) yaptırıldı ve çevresine Müslümanlar iskân edildi. Katolikler ve Müslümanlar arasında 17. yüzyıl başlarında zaten var olan gerilimin şiddeti, yüzyııın sonunda da aynıydı. Müslümanlar, cami çevresinde oturan Katoliklerin ihracı için farklı zamanlarda kadıya gittiler. Aleyhlerine hükümler verildiyse de Katoliklerden bazıları civarda oturmaya ısrarla devam ettiler. Fransız elçisinin hâmi olarak açtı̆ı karşı davada ise bu defa haklı çıkanlar Katoliklerdi. Ancak, durumu tersine çevirme konusunda Müslümanlar oldukça kararlıydılar. Bu çalışma, birbirine yakın olan Arap Camii ve Yeni Cami çevresinde oturma hakkı bağlamında, Müslümanlar ve Katolikler arasında gerçekleşen ve yıllara yayılan hukuk mücadelesine odaklanmaktadır. Söz konusu camiler hakkında bilgi verildikten sonra anlaşmazlıkların yansıdığı belgeler incelenerek ayrıntılara ışık tutulmaya çalışılacaktır.

Anahtar Kelimeler: Galata Yeni Cami, Arap Camii, Yangın, Osmanlı Katolikleri, San Françesko Kilisesi, Gülnuş Valide Sultan

\section{ABSTRACT}

The Church of St. Dominic, one of the biggest Christian churches in Galata, was converted to a mosque by Mehmed II around 1475. Following the settlement of Spanish Moriscos, the temple took the name of the Arab Mosque. The New Mosque, sponsored by Gülnuş Valide Sultan, was built on the spot where another important church in the same region and very close to Arab Mosque, that of St. Francis, had stood before the 1696 fire. The tension between Catholics and Muslims remained intense throughout 
the seventeenth century. Muslims time and again applied to the Muslim sharia court in order to expel the Catholics from the vicinity of the mosque and despite the repeated court rulings, some Catholics insisted on residing there. In a countersuit filed by the French ambassador, it was this time Catholics' turn to prevail. Yet, the Muslims were still intransigent to turn the situation in their favor. This essay focuses on the legal struggle spanning several years between the Muslims and the Catholics over the right to reside in the vicinity of the New and Arab mosques. After providing detailed information about these two temples, it will try to shed light on the issue by analyzing archival documents related to the legal conflict.

Keywords: Galata New Mosque, Arab Mosque Fire, Ottoman Catholics, San Francis Church, Gulnuş Valite Sultan

\section{EXTENDED ABSTRACT}

The St. Dominic Church, one of the biggest churches in Galata, was converted into a mosque by Mehmed the Conqueror (Fatih) around 1475. As a result of the settlement of Muslims from Spain, this place of worship began to be called the Arab Mosque. After the fire of 1696, a mosque (Galata New Mosque) was built by Gülnuş Valide Sultan, replacing Galata's most important Latin Catholic church (St. Francis Church) and Muslims were settled around it. The fire of 1696 caused the church to be completely erased from history.

The presence of Venetian state crests of the Holy Alliance against the Ottomans within the church created great misfortune for the buildings' future. This position, which was noted in the inspection report, was the main reason behind the conversion to a mosque. In addition, the district governor ( $q \bar{a}$ immakām) of Istanbul, the judge (qāọi) and local governor (voyvode) of Galata came to seize the church after the fire, with the crowds gathered outside chanting slogans in favour of converting the place into a mosque. The surrounding "houses of the infidels" (kefere hāneleri) would now become the accommodation of the Islamic community (ehl-i İslām sākin). For this purpose, lands belonging to non-Muslims were purchased and reconstruction works began immediately under the patronage of Gülnuş Valide Sultan.

The severity of the tensions that already existed in the early seventeenth century between Latin Catholics and Muslims was similar to those at the end of the century. Muslims went to the qāḍ $\bar{i}$ at different times in an effort to expel the Latin Catholics living around these two mosques and made attempts to rent houses around the mosque to Muslims, not to nonMuslims, and to expel non-Muslims from the region. For this purpose, they presented four petitions ('ard $-1, h \bar{a} l)$, one belonging to the pre-construction, and the others belonging to the post-construction of Galata New Mosque, according to current findings. Although there had been counter-moves by non-Muslims, the only detectable example was the petition of the French ambassador.

After the great fire that broke out in Galata on 4 May 1696, two imperial edicts (firmāns) with the same content were issued. The first of the edicts addressed to the Istanbul district governor and the Galata qā 
important one, at the end of the month. In the documents, this fire which caused the "infidels" (kefere) to come and settle in the places where Muslims previously lived was interpreted as God's wrath. In order for His anger to be hastily placated, the places that were in the hands of non-Muslims should be transferred or sold to Muslims again.

The issue of the decrease in congregation (taqlïl-i cemā'at) in 1700 continued to be the most important dispute between the parties. As a matter of fact, it is stated that non-Muslims bought or rented houses around the newly built mosque and this was the reason for reduction in the congregation of the mosque, according to the petition presented to the qāọi by al-Hajj Mehmed Aga, who was Gülnuş Valide Sultan's steward (ketkhüdā). While care was taken to increase the Muslim population around the New Mosque, other problems arose in terms of non-Muslims. The 1710 petition signed by the "servile community of the poor district" (bende ahālì-i mahalle fuqarāları) which points to the settlement and expulsion contestations, reflects the social and psychological aspects of the expulsion and settlement process, which became more acute with the construction of Galata New Mosque.

In the face of these events, the French ambassador Pierre Puchot took action and presented a petition to the sultan. According to the ambassador, there were more than three hundred Muslim houses around the Arab Mosque and it was not possible that the Frankish community (Efrenc tă'ifesi), which had been living there for a long time, would cause the congregation to decrease. Some malicious people had given false information on the subject, and efforts to prove the complaints were made by gathering people from other neighborhoods. The order written in response to this petition was exactly as the envoy wanted. However, the Muslims were quite determined to reverse the situation.

This study focuses on the legal struggle that took place between Muslims and Latin Catholics in the context of the right to live around the Arab and New Mosques. After providing information about the mosques in question, the documents reflecting the disputes will be examined and light will be shed on their details. 


\section{Giriş}

Cenevizli podesta Angelo Giovanni Lomellino'nun, İstanbul'un fethi sonrasında Galata'nın anahtarlarını vezir Zağanos Paşa'ya teslim etmesi üzerine Galatalılara ahidnâme verilmiştir.' Osmanlı döneminde sahip olduğu gayrimüslim nüfusu ile dikkati çeken Galata'da Müslüman mahalleleri de zamanla teşekkül etmiştir. ${ }^{2}$ Ilk olarak, San Domeniko Kilisesi bizzat Fatih tarafından 1475 dolaylarında camiye dönüştürülmüştür. ${ }^{3}$ Başlangıçta Câmi-i Kebîr denilmesine karşılık, İspanya'dan gelen Müslümanlardan ${ }^{4}$ bu çevrede yerleşenler dolayısıyla bu cami “Arap Camii" adı ile anılır olmuştur.

Birçok vakıf eserin banisi Gülnuş Valide Sultan, ${ }^{5}$ Arap Camii'ne yakın konumda bulunan San Françesko Kilisesi'nin yerine 1696 yangını sonrasında cami yaptırmıştır. Bu da Galata'da mimari ve nüfus yönünden bir değişim ve dönüşüme sebep olmuştur.

Gülnuş Emetullah Sultan'ın valide sultan olmasından (Şubat 1695) bir yıl sonra (Mayıs 1696) gerçekleşen bu dönüşüm, adı geçen iki mabet çevresindeki bazı Müslüman ve Hıristiyanlar arasında 1693 yılında başlamış olan mekânsal ihtilafları da beraberinde getirmiş ve konu, yıllara yayılan hukuki bir mesele halini almıştır.

1 Galata'nın Osmanlı toprağı olması, Frenklere verilen ahidname, 1455 yılında yapılan tahrir hakkında değerlendirmeler ve diğer ayrıntılar için bkz. İskender Yanko Hoci, "Galata'nın Osmanlıara Teslîmi," TOEM, 5/25 (1330), 49-53; Mahmut H. Şakiroğlu, "Fatih Sultan Mehmet'in Galatalılara Verdiği Fermanın Türkçe Metinleri," Tarih Araştırmaları Dergisi 14/25 (1981-1982), 211-24; Halil İnalcık, "Ottoman Galata: 1453-1553," Essays in Ottoman History içinde (İstanbul: Eren Yay., 1998), 275-376; Rumca olan ahidnâmenin Türkçe sureti, Galata'nın bir Osmanlı idari birimi olması ve Cenevizlilerin zimmî statüsüne alınma süreci için ayrıca bkz. K. İlker Bulunur, Osmanlı Galatası [1453-1600] (İstanbul: Bilge Kültür Sanat, 2014), 60-5; K. Ilker Bulunur, "II. Mehmed tarafından Galatalılara Verilen 1453 Ahidnâmesi ve Buna Yapılan Eklemeler Hakkında Yeni Bilgiler," Tarih Dergisi 50 (2009/2), 59-85; Fariba Zarinebaf, Mediterranean Encounters: Trade and Pluralism in Early Modern Galata (Oakland, California: University of California Press, 2018), 21-41; Osmanlı tebaası olması ile Cenevizlilerin ticari, kültürel ve politik duruşları hakkında bkz. Céline Dauverd, "Cultivating Differences: Genoese Trade Identity in the Constantinople of Sultan Mehmed II, 1453-81," Mediterranean Studies Special Issue: The Mediterranean Voyage, 23/2 (2015), 94-124.

2 Louis Mitler, "The Genoese in Galata: 1453-1682," International Journal of Middle East Studies 10/1 (1979), 72; Edhem Eldem, "Ottoman Galata and Pera Between Myhth and Reality," From "milieu de memoire" to "lieu de memoire" içinde, ed. Ulrike Tischler (Münhcen: Martin Meidenbauer, 2006), 19-36; Galata'da Müslüman mahallelerinin vakıflar ve camiler dolayısıyla oluşumu üzerine genel bilgi için bkz. Zarinebaf, Mediterranean, 52-6.

3 Fatih Sultan Mehmed Vakfiyeleri, haz. Cengiz Şeker (Ankara: Başbakanlık VGM - İstanbul: Çamlıca Kültür ve Yardım Vakfı, t.y.), 23.

4 Endülüs Müslümanları hakkında genel bilgi için bkz. Mehmet Özdemir, "Moriskolar," DiA 30 (2015), 288-91.

5 Kaynaklarda, Giritli bir cariye olarak saraya getirildiği belirtilen Haseki Gülnuş Emetullah Sultan, 1687'de IV. Mehmed'in tahttan indirilmesi ile Eski Saray'a gönderildi. Oğullarından II. Mustafa'nın 1695'te, III. Ahmed'in de 1703'te sırasıyla tahta çıkmaları ile valide sultanlık makamına iki defa geldi. 1715'te valide sultanken vefat etti. Gülnuş Valide Sultan'ın vakıfları üzerine önemli ve belgesel açıdan kapsamlı bir çalışma için bkz. Emine Berksan, “II. Mustafa ve III. Ahmed'in Valideleri Emetullah Gülnûş Sultan ve Vakıfları” (Yüksek Lisans Tezi, İstanbul Üniversitesi, 1998); Ayrıca bkz. Ali Akyıldız, Haremin Padişahı Valide Sultan: Harem'de Hayat ve Teşkilat (İstanbul: Timaş, 2017), 402-11; Mehmet İpşirli, “Gülnûş Emetullah Sultan," DiA 14 (1996), 248-49; Ayrıntılı biyografik bilgi için bkz. M. Çağatay Uluçay, Padişahların Kadınları ve Kızları, 2. bs. (Ankara: Türk Tarih Kurumu, 1985), 65-7; Betül Ipşirli Argıt, Rabia Gülnuş Emetullah Sultan (1640-1715) (İstanbul: Kitap Yayınevi, 2014), 17 , 32 vd.; Akyıldız, Haremin Padişahı, 399-402; Mustafa Güler, Gülnûş Vâlide Sultan'ın Hayatı ve Hayrâtı (İstanbul: Çamlica, 2006), 19-31. 


\section{Cami-i Kebîr nâm-ı diğer Arap Camii}

Arap Camii, Dominiken tarikatı tarafından 14. yüzyıl başlarında San Paolo ve San Domeniko adına kurulan bir Katolik kilisesi iken, Fatih tarafından 1475'ten sonraki bir tarihte camiye çevrilmiştir. ${ }^{6}$ Fatih vakfiyelerinde "Galata Camii” şeklinde geçen yapının çevresine 16. yüzyılda İspanya ve Portekiz'den gelen Moriskoların yerleştirildiği ve bunun bir sonucu olarak da mevcut isminin ileriki yıllarda Arap Camii'ne dönüştüğü bilinmektedir.7

Evliya Çelebi'nin "kadîm" şeklinde nitelediği ve "niçe kerre kenîse ve câmi“ olmışdır” dediği Arap Camii'nin tarihi hakkında literatürde süregiden bir belirsizlik hakimdir. San Domeniko Kilisesi'nden dönüştürüldüğü kesin olarak bilinmesinin yanı sıra, Emevi kumandanı Mesleme b. Abdülmelik'in İstanbul kuşatması sırasında (716-717) yaptırdığı caminin de burası olduğuna dair görüşler ileri sürülmüştür.9 İspanya'dan göçe zorlanan Müslüman Araplardan bu cami çevresinde iskân edilenlerin olması, yapı hakkındaki bu tür rivayetleri daha da güçlendirmiştir. ${ }^{10}$

Evliya Çelebi'nin bildirdiğine göre 1630'larda 18 Müslüman, 70 Rum, 3 Frenk, 1 Yahudi ve 1 de Ermeni mahallesinin bulunduğu Galata'da Arap Camii tarafında hiç gayrimüslim yoktur. ${ }^{11}$ Hatta, Arap Camii çevresinde yerleşmiş olan Müslümanlar, buraya gayrimüslimlerin değil yerleşmelerine buradan geçmelerine dahi izin vermemektedirler. Zira, Katolik İspanya'dan göçe zorlanmaları nedeniyle Hristiyanlara öfke duymaktadırlar:

\footnotetext{
“Ve ahâli-i mahalle elinde Ebü'l-feth'den berü hatt-ı şerîfleri vardır. Kâfiri komazlar ve silâh ile nasârâ görseler ol ân amân [ü] zamân virmeyüp katl iderler. Zirâ ekseriyâ İspanya'dan Sultân Ahmed 'asrında gelen ciğer-hûn mübtecil tâ'ifesi müslimânlarıdır kim İspanya'dan küffârdan ciğerleri hûn olmışdır."12
}

6 Semavi Eyice, camiye dönüştürmenin 1475'e doğru olduğunu söylerken, W. Müller-Wiener, '1475-1478 arasında bir tarih olmalıdır' der. Bkz. Semavi Eyice, “Arap Camii,” DiA 3 (1991), 326; Wolfgang Müller-Wiener, İstanbul'un Tarihsel Topografyası: 17. Yüzyıl Başlarına Kadar Byzantion-Konstantinopolis-İstanbul, çev. Ülker Sayın (İstanbul: YKY, 2001), 79-80.

7 Eyice, “Arap Camii,” 326; Müller-Wiener, İstanbul'un Tarihsel, 80; Galata'daki Arap yerleşiminin süreçleri hakkında bkz. İnalcık, “Ottoman Galata,” 324-27.

8 Evliya Çelebi, Seyahatnâme, I, haz. O. Şâik Gökyay (İstanbul: YKY, 1996), 183.

9 Bu görüşe sahip olanların başında Evliya Çelebi gelmektedir. Evliya, Cami'nin “Arap” ismini taşıması ve kıblesinin de "dürüst" ve "mihrâbı[nın] kıbleye müteveccih" olmasının buna işaret ettiğini belirtmektedir. Bkz. Evliya Çelebi, Seyahatnâme, I, 30, 182-3; Buna iştirak eden diğer bir kaynak için bkz. Hâfız Hüseyîn Ayvansarâyî, Hadîkatü'lCevâmi' (İstanbul Câmileri ve Diğer Dînî-Sivil Mi'mârî Yapılar), haz. Ahmed Nezih Galitekin (İstanbul: İşaret, 2001), 424-27.

10 Yapının tarihine değinen bütün araştırmalarda bu konu tartışılmaktadır. Bkz. Celal Esad Arseven, Eski Galata ve Binâları, haz. Dilek Yelkenci (İstanbul: Çelik Gülersoy Vakfı Yay., 1989), 46-50; Eyice, “Arap Camii,” 326; İnalcık, "Ottoman Galata," 325; Bulunur, Osmanlı Galatası, 179-83; Cami'nin kimlik bakımından aidiyeti ve tarihi hakkında geniş bir özet için bkz. Olgay Söyler, "Bizans-Arap Savaşları Gölgesinde Arap Camisi veya Galata Aziz Paulus Kilisesi," Vakıf Restorasyon Yılığı 16 (2018), 80-87; Kiliseden camiye dönüşümü hakkında ayrıca bkz. Zarinebaf, Mediterranean, 46-8; Cami'yi mimari açıdan inceleyen değerli bir çalışma için bkz. Halûk Çetinkaya, "Arap Camii in Istanbul: Its Architecture and Frescoes," Anatolia Antiqua 18 (2010), 169-88.

11 E. Eldem, özellikle Rum mahallelerinin çokluğu olmak üzere bu rakamları abartılı ve yanıltıcı bulmaktadır. Eldem, "Ottoman Galata," 31.

12 Evliya Çelebi, Seyahatnâme, I, 183. 


\title{
Galata Yeni Valide Camii
}

Osmanlı İstanbul'unda olduğu gibi Osmanlı Galata'sında da küçük büyük birçok yangın meydana gelmiştir. ${ }^{13}$ İki yangının yaşandığı 1696 yılı ayrı bir öneme sahiptir. Bunlardan $6 \mathrm{Ma}-$ yıs 1696 (4 Şevval 1107) tarihinde çıkan büyük yangın sonrasında Galata'nın bir bölümünde sosyal ve dinî motifli bir değişim yaşanmıştır. Silahdar, daha önce benzerinin görülmediğini söylediği yangını şöyle anlatır:

\begin{abstract}
“Üçünci şenbih gicesi bi-emri'llâhi te ‘âlâ altıncı sâ‘atde Tophâne Kapusu hâricinde vâki“ Kâdî Furûnı nâm bir börekci furûnundan zuhûr iden âteş yalunı nâgehânî Galata Hisârı dîvârı üzerinden içerü girüp sağlu ve sollı gidüp Arab Câmi'i'ne va[r]ınca bi'l-külliyye enderûn-ı hisâr ihrâk [u] bi'n-nâr olup ve hâric-i hisâr dahi Tophâne kurbünde Debbâğhâne'den alup dîvâr sırasıyla gidüp Galata Gümrügü'nden gayrı Kalafat Yeri'nde Sebîlhâne'de nihâyet bulunca leb-i deryâda binâ ve süknâ ve dekâkînden eser kalmayup cümle yandı. Bir târîhde Galata böyle başdan başa değin yanduğı mesmû‘ ve müşâhede olunmadı."14
\end{abstract}

Bu yangından etkilenen yerlerden biri de Arap Camii'ne yakın bir mevkide bulunan ve 13. yüzyıl eseri olan San Françesko Kilisesi'ydi. Fethe kadar San Paolo ve San Domeniko Kilisesi İstanbul'un en önemli Katolik kilisesiydi. Bizans döneminde Ayasofya'nın en önemli Ortodoks mabedi olması gibi, San Domeniko Kilisesi de Katolikler açısından böyleydi. Söz konusu kilisenin Arap Camii'ne dönüşmesi sonrasında ise onun yerini San Françesko Kilisesi aldı. ${ }^{15}$ “İstanbul'daki Latin cemaatin coğrafî ve ruhanî odak noktasını temsil eden” 16 kilise aynı zamanda Galatalı Hıristiyan Katoliklerin merasim tertip ettikleri ve sosyalleştikleri mekân olarak önemli bir fonksiyona da sahipti. ${ }^{17}$

13 İstanbul ve Galata'da çıkan yangınlar hakkında bkz. Mustafa Cezar, "Osmanlı Devrinde İstanbul Yapılarında Tahribat Yapan Yangınlar ve Tabii Âfetler," Türk San'atı Tarihi Araştırma ve Incelemeleri I içinde (İstanbul: Güzel Sanatlar Akademisi Yay., 1963), 327-414; M. Ali Beyhan, “Osmanlı Devrinde İstanbul Yangınları," Afetlerin Gölgesinde İstanbul: Tarih Boyunca İstanbul ve Çevresini Etkileyen Faktörler içinde, ed. Said Öztürk (İstanbul: IBBB, t.y.), 187-312; Kenan Yıldız, “Şehir Topografyasına Etkisi Bakımından İstanbul Yangınları,” Antik Çağ'dan XXI. Yüzyıla Büyük İstanbul Tarihi: İstanbul'un Emperyal Dönüşümleri, Dünya Ölçeğinde İstanbul, Topoğrafya ve Yerleşim, I içinde, proje yön. M. Âkif Aydın, ed. Coşkun Yılmaz (İstanbul: İBB Kültür A.Ş - ISAM, 2015), 564-81.

14 Silâhdar Fındıklılı Mehmed Ağa, Silâhdar Fındıklıı Mehmed Ağa Nusretnâme: Inceleme - Metin (1 106-1133/1 6951721), haz. Mehmet Topal (Ankara: Türkiye Bilimler Akademisi, 2018), 229.

15 Gualberto Matteucci, Un Glorioso Convento Francescano sulle rive del Bosforo: il S. Francesco di Galata in Constantinopoli (Firenze: Edizioni Studi Francescani, 1967), 8; Vanessa R. de Obaldia, “A Shared Space and Shared Functions: From a Latin Catholic Church to an Islamic Vakıf in Ottoman Galata," Endowment Studies 2/2 (2018), 134'ten naklen G. Hofmann, Il Vicariato Apostólico di Costantinopoli 1453-1830 (Rome: 1935), 49-53; Muzaffer Özgüleş, The Women Who Built the Ottoman World: Female Patronage and the Architectural Legacy of Gülnuş Sultan (London - New York: I. B. Tauris, 2017), 105-6.

16 Eric R. Dursteler, İstanbul'daki Venedikliler: Yeniçağ Başlarında Akdeniz'de Millet, Kimlik ve Bir Arada Varoluş, çev. Taciser Ulaş Belge (İstanbul: T. İş Bankası, 2012), 217.

17 Obaldia, "A Shared Space," 148. 
Galata'nın bu en büyük ve aynı zamanda en zarif kilisesi, kıyamet beklentilerinin etkisiyle 1585-1597 yılları arasında ibadete kapatıldı. ${ }^{18}$ Evliya Çelebi, 1630’larda gezdiği ${ }^{19}$ San Françesko Kilisesi hakkında "evce ser-çekmiş çâr-gûşe bir nâkûshânesi var" diyerek çan kulesinin heybetine dikkat çekmektedir. ${ }^{20}$ Diğer taraftan "dâhilinde ve hâricinde sûr-ı 'acîbe ve garîbe menkûş tasvîrler var kim gûyâ zî-rûhdur" ifadeleriyle Kilise'nin sanatsal zenginliğine atıfta bulunmaktadır. ${ }^{21}$ Fakat Kilise, sahip olduğu bütün güzelliklerini 1639 yangınında kaybetmiş, ${ }^{22}$ yeniden inşa izni alınmış olsa da öncekinden daha küçük olarak yapılabilmişti. ${ }^{23}$ Buna karşılık, Antakya Rum Patriği 1650'de ziyaret ettiği bu mabedi Ayasofya'ya benzetecek kadar görkemli ve şık bulmaktaydı. ${ }^{24}$ Nisan 1660 yangınında ${ }^{25}$ Kilise tekrar yandı ve bu sıralarda Venedik'e karşı devam eden Girit Savaş ${ }^{26}$ nedeniyle uzunca bir süre harap vaziyette kaldı. 1669'da Kandiye'nin fethi ve Venedik ile yapılan barış sonrasında ancak 1670'te yeniden inşa edilebildi. ${ }^{27}$

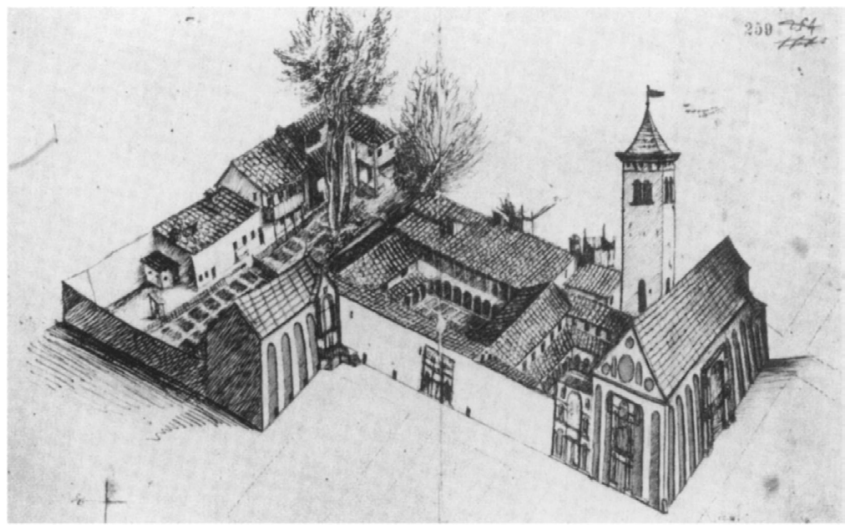

(San Françesko Kilisesi. Kaynak: Gualberto Matteucci, Un Glorioso Convento Francescano sulle rive del Bosforo: il S. Francesco di Galata in Constantinopoli, Firenze: Edizioni Studi Francescani, 1967'den naklen Archivio di Propaganda Fide S. R. 163, f. 258v - 59r.)

18 Charles A. Frazee, Catholics and Sultans: The Church and the Ottoman Empire 1453-1923 (Cambridge: Cambridge University Press, 1983), 72, 79.

19 Bu tarih için bkz. Gualberto Matteucci, Un Glorioso, 332.

20 Evliya Çelebi, Seyahatnâme, I, 183.

21 Evliya Çelebi, Seyahatnâme, I, 183.

22 Frazee, Catholics, 96.

23 Silahdar Findıklıı Mehmed Ağa, "Zeyl-i Fezleke (1065-22 Ca.1106 / 1654-7 Şubat 1695): Tahlil ve Metin" haz. Nazire Karaçay Türkal (Doktora Tezi, Marmara Üniversitesi, 2012), 207; "Tarih-i Nihâdî (152b-233a) (transkripsiyon ve değerlendirme)" haz. Hande Nalan Özkasap (Yüksek Lisans Tezi, Marmara Üniversitesi, 2004), 46.

24 Matteucci, Un Glorioso, 331-32.

25 Hrand D. Andreasyan, “Eremya Çelebi'nin Yangınlar Tarihi," Tarih Dergisi 27 (1973), 70; Bu yangın hakkında kısa bir değerlendirme için bkz. Kenan Yıldız, 1660 İstanbul Yangını ve Etkileri: Vakıflar, Toplum ve Ekonomi (Ankara: Türk Tarih Kurumu, 2017), 168-69.

26 1645-1669 yılları arasında uzun bir zamana yayılan Girit Kuşatması ve fethi için bkz. Ersin Gülsoy, Girit'in Fethi ve Osmanlı Idaresinin Kurulması (1645-1670) (İstanbul: TATAV, 2004).

27 Evliya Çelebi, Seyahatnâme, I, 183; Eremya Çelebi Kömürciyan, İstanbul Tarihi: XVII. Asırda Istanbul, çev. Hrand D. Andreasyan, haz. Kevork Pamukciyan (İstanbul: Eren Yay., 1988), 36; Rinaldo Marmara, Bizans'tan Günümüze İstanbul Latin Cemaati ve Kilisesi, çev. Saadet Özen (İstanbul: Kitap Yayınevi, 2006), 33. 
1696 yangını ise Kilise'nin tarih sahnesinden tamamen silinmesine neden oldu. ${ }^{28}$ Kilise binası ayakta kalmış olsa da, içerideki mobilya ve enstrümanlar zarar görmüştü. Daha da kötüsü kilisenin bütün akarları yok olmuştu. ${ }^{29}$ Yangından hemen sonra cami yapılmak üzere arsasına el konulan Kilise temelinden yıkıldı:

\begin{abstract}
“Bi-hasebi'l-iktizâ yanan kilisalar ta'mîrine icâzet virilüp ancak Venedik Kilisası temelden yıkılup yerine devletlü vâlide sultân hazretleri bir mükellef câmi'-i şerîf binâ idüp azîm sular getürtmekle Galata'yı pâk ve yeniden ihyâ eyledi." ${ }^{30}$
\end{abstract}

Çağdaş iki Fransız seyyah La Motraye ve Tournefort, Kilise'yi bir meyhaneye çevirmiş olan İtalyanların bu sonuçta büyük payları olduğunu söylemektedirler. ${ }^{31}$ Yapının kilise ve cami dönemlerini inceleyen Vanessa de Obaldia bu konuyla ilgili olarak “yeniden inşa için maddi kaynak sağlanana kadar, harap kilisenin şarap dahil bazı eşyaların muhafaza edildiği bir depo gibi kullanılmış olabileceği" yorumunda bulunmaktadır. ${ }^{32}$ San Françesko Kilisesi hakkında değerli bir monografisi bulunan Matteucci'ye bakılırsa Kilise'nin bir şarap mahzeni olarak kullanıldığı, yangından kısa bir süre önce Kilise ve Manastır müştemilatında yapılan teftişte ortaya çıkmıştı. Osmanlılara karşı Kutsal İttifak'ta yer alan Venedik'e ait devlet armalarının Kilise dahilinde bulunması ise yapının geleceği açısından büyük bir talihsizlik oluşturdu. ${ }^{33}$

28 Paolo Girardelli, "Architecture, Identity, and Liminality: On the Use and Meaning of Catholic Spaces in Late Ottoman Istanbul," Muqarnas 22 (2005), 236.

29 M. A. Belin, Histoire de la Latinité de Constantinople, $2^{\mathrm{e}}$ ed., revue, augmentée et continuée jusqu'a notre temps par Le R. P. Arséne de Chatel (Paris: A. Picard, 1894), 208-9; Matteucci, Un Glorioso, 287-88; Marmara, Bizans'tan Günümüze, 33.

30 Silâhdar, Nusretnâme, 229; Capuchin ve Cizvit kiliselerinin inşa izinleri Karlof̧̧a Antlaşması ile verilmişti. Bunların keşif süreçleri için bkz. Yıldız, 1660 Istanbul Yangını, 97-8; Ayrıca Galata'da Sultan Bayezid ve Bostan mahallelerinde bulunan Hristos ve Aya Yani kiliselerinin inşa izinlerine dair bkz. Galata Şer' iyye Sicili (GŞS), 171, 90b/1 (Evl L 1108/Nisan 1697) ve GŞS, 174, 122b/1, (Evs S 1110/Ağustos 1698), 135b/1 (Evs Za 1110/Mayıs 1699), 136a-137a (7 Z 1110/6 Temmuz 1699).

31 Aubry de La Motraye, La Motraye Seyahatnamesi, çev. Nedim Demirtaş (ístanbul: İstiklal Kitabevi, 2007), 73-74; Joseph de Tournefort, Tournefort Seyahatnamesi, II. Kitap, ed. Stefanos Yerasimos, çev. Teoman Tunçdoğan (İstanbul: Kitap Yayınevi, 2005), 37.

32 Obaldia, "A Shared Space," 143.

33 Matteucci, Un Glorioso, 290-91. 
Teftiş raporunda dikkat çekilen bu son madde, camiye dönüştürmenin arka planındaki asıl nedenmiş gibi durmaktadır. ${ }^{34}$

Buradan hareketle, camiye çevirme düşüncesinin, asıl amacından saptırılarak 'Kilise'nin bir meyhaneye dönüştürüldüğü’ algısı ile haklı bir gerekçeye bağlanmak istendiği ileri sürülebilir. Nitekim ‘asıl amacına uygun kullanılmadığı ortaya çıkan' Kilise'nin camiye dönüştürülmesi böylelikle kaçınılmaz hale gelmiş olmalıdır. Buna ek olarak İstanbul kaymakamı, Galata kadı ve voyvodası, yangın sonrasında Kilise'yi zaptetmek üzere geldikleri sırada dışarıda toplanan halkın buranın camiye çevrilmesi lehine slogan atmaları, ${ }^{35}$ kamuoyu algısının da resmi makamlarca yürütülen söz konusu politikaya uygun düştüğünü göstermektedir.

Tournefort'un, Eminönü Yenicami'ye göre sıradan bulduğu ${ }^{36}$ bu mabede Türkler “Valide Camii" ismini yakıştırırlarken, Frenkler ironik ve "oksimoronik" ${ }^{37}$ bir adlandırma ile "San Françesko Camii" dediler. ${ }^{38}$ Kilise mezarlığındaki kemikler Beyoğlu Mezarlığı'na taşınırken, ${ }^{39}$ çevredeki “kefere hâneleri”nde de artık "ehl-i İslâm sâkin” olacaktı. Bu amaçla gayrimüslimlere ait arsalar satın alındı. ${ }^{40}$ Masrafları, Valide Sultan tarafından karşılanmak üzere yeniden inşa çalışmalarına hemen başlandı. Defterdar Sarı Mehmed Paşa bunu şöyle nakleder:

\begin{abstract}
“Galata'da muhterik olan kilise, câmi'-i şerîf olmak üzere tasmîm ve etrâfında olup, hark olan kefere hâneleri dahi bi'l-cümle ehl-i islâm sâkin olmak üzere, 'ismetlü Vâlide Sultân hazretleri taraflarından binâsına mübâşeret itmâm-pezîr olup ve hademe ve mürtezıkalarının iktizâ iden vezâyifleri ta'yîn ile müşârün-ileyhâ hazretleri bu hasenât-ı celîleye muvaffak oldular"41
\end{abstract}

34 Bu dönüştürme, uluslararası askeri ve politik durum açısından açıklanabilir bir niteliğe sahiptir. Nitekim aslında, Kilise'ye karşı gösterilen güvensizlik tavır ve refleksi, bu sıralarda savaşılan bir devlet olan Venedik dolayısıyladır. Bu açıdan bakıldığında, meselenin "Kadızadeli" hareketine, salt dinî tutuculuğa veya gayrimüslimlere karşı düşmanlığa bağlanması zorlama bir yorum olmaktadır. Muzaffer Özgüleş'in mimarlık tarihi açısından son derece kıymetli olan tez, makale ve kitabında konu etraflıca işlenmekle birlikte, Eminönü Yenicami ile Galata Yeni Cami'nin inşası süreçlerine bu yönde açıklamalar getirilmektedir. Özgüleş, The Women, 105-6, 112, 139; Fakat, konu ekseninde bu söylemin tersi argümanları içeren yayınların Özgüleş tarafından dikkate alınmamış olması önemli bir eksiklik oluşturmaktadır. İslâmlaştırma argümanını savunanların başında Marc David Baer gelmektedir. Bkz. Baer, IV. Mehmet Döneminde Osmanlı Avrupası'nda Ihtida ve Fetih, çev. Ahmet Fethi (İstanbul: Hil Yayın, 2009), 137-195; Kitabın bir eleştirisi için bkz. Abdülkadir Özcan, “istanbul'un Eminönü Semti XVII. Yüzyılda mı İslâmlaştırıldı?," Osmanlı Araştırmaları 37 (2011), 206-213; Baer ve başka çalışmalarda ileri sürülen bu tür argümanların tartışıldığı çalışma için bkz. Yıldız, 1660 Istanbul Yangını, 161-234; Kenan Yıldız, "Doğruluğu Tartışmalı Bir Tartışma: 1660 Yangını İstanbul'un İslâmlaşmasına Etki Etti mi?," Osmanlı İstanbulu Uluslararası Sempozyum-I (29 Mayıs - 1 Haziran 2013), İstanbul 29 Mayıs Üniversitesi, (İstanbul 2014), 197-242.

35 Matteucci, Un Glorioso, 300.

36 Tournefort, Seyahatname, II, 25.

37 Bu tanımlama Vanessa de Obaldia'ya aittir. Bkz. "A Shared Space," 140.

38 Tournefort, Seyahatname, II, 37.

39 Marmara, Bizans'tan Günümüze, 109.

40 İpşirli Argıt, Rabia Gülnuş, 177'den naklen TSMA E-145/9 (y. t. TSMA E-101/2-32).

41 Defterdar Sarı Mehmed Paşa, Zübde-i Vekayiât: Tahlil ve Metin (1066-1116/1656-1704), haz. Abdülkadir Özcan (Ankara: TTK, 1995), 606-7. 


\section{Müslümanlar ve Katolikler Arasındaki Hukuk Savaşları}

Evliya Çelebi, IV. Murad zamanında yapılan tahrire dayalı olarak Galata'da gayrimüslim sayısını 200 bin, Müslüman sayısını da 64 bin olarak vermektedir:

“Zîrâ bu iki kal'adan mâ‘adâ tâ Tophâne'ye varınca iki kal'a içi mâlâ-mâl yedi kıral-ı Frengi ve cümle nasârâ mâlâ-mâldır. Murâd Hân tahrîri üzre iki kerre yüz bin kâfir ve altmış dörd bin müslim vardır. Hudâ hıfz ide. Yetmiş kefere kenîsesi vardır."42

Abartılı gibi görünen bu nüfus verileri, Müslüman ve gayrimüslim mahalle sayıları dikkate alındığında en azından oransal farkı yansıtması bakımından belirleyici olmaktadır. 17. yüzyıl ortaları için de bu bilgiler geçerli sayılabilir fakat, zamanla bölgede Müslümanların sayısı arttığı gibi, gayrimüslimlerden de Arap Camii çevresine yerleşenler olmuştur. Zira Galatalı Müslümanlar, yüzyılın sonlarından itibaren Cami çevresinde bulunan evlerin gayrimüslimlere değil Müslümanlara kiralanması ve gayrimüslimlerin bölgeden çıkarılması için girişimlerde bulunmuşlardır. Bu maksatla, şimdiki tespitlere göre biri Galata Yeni Cami'nin yapımı öncesine, diğerleri de sonrasına ait olan dört arzıhal sunmuşlardır. Gayrimüslimlerin karşı hamleleri olduysa da, tespit edilebilen tek örnek Fransız elçisinin verdiği arzıhaldir.

1693 tarihli ilk arzıhalde Galata'da bazı kimseler “mücerred ahz ü celb içün” yani sadece sorun çıkarmak için "Frenk tâifesin civârımızda istemeziz" diyerek Arap Camii çevresinde oturan Frenkleri bu bölgeden uzaklaştırma gayretine girmişlerdir. Fakat, ihtilafın hikâyesi daha eskiye gitmektedir. Anlaşmazlığın ortaya ilk çıktığı dönemin kadısı olan Ali Türk’ten durum sorulduğunda "keferenin müslimîn beynlerinde süknâları hakkında fukahâ ihtilâf etmişlerdir mu‘temed olan süknâlarının cevâzıdır lâkin süknâları taklîl ve ta‘tîl-i cemâ‘at-i müslimîne bâ‘is olmamağla mukayyeddir ve re'âyâ-yı mezkûrdan sâkin oldukları menzillerin câmi'-i şerîfden bu'du olup süknâları taklîl ve ta'tîl-i cemâ'at-i müslimîne bâ'is değildir" diyerek Müslümanlar arasında gayrimüslimlerin ikametinin taklîl-i cemaate ${ }^{43}$ sebep teşkil etmemesi kaydıyla meşru görüldüğü, şikâyette bulunanların ise gayrimüslimlere karşı “ahz ü celb garaziyle” hareket ettikleri cevabı alınmıştır. Dönemin Fransız elçisi Şatonf Baronu'nun [Baron de Chateauneuf] arzıhalinin de benzer şikâyet ve tespitler içeriyor olması dolayısıyla İstanbul kaymakamı ve

42 Evliya Çelebi, Seyahatnâme, I, 183.

43 Cami cemaatinin sayısal olarak azalması anlamına gelen ve dinî otorotitelerce istenmeyen bir olgu olan "taklîl-i cemâ'at" bahsi için bkz. Yıldız, 1660 İstanbul Yangını, 224-34. 
Galata kadısına bu bilgilerin dikkate alınması, arzıhalde belirtilen hususların yerinde tahkiki ve gereğinin yapılması emri yazılmıştır.44

Galata'da 4 Mayıs 1696'da çıkan büyük yangından sonra aynı içerikte iki ferman çıkarılmıştır. İstanbul kaymakamı ve Galata kadısına hitaben yazılan fermanların ilki Mayıs ayının ortalarında, daha kapsayıcı ve önemli olan ikincisi ise ayın sonlarında yazılmıştır. Belgelerde, daha önce Müslümanların yaşadıkları yerlere “kefere"nin gelip yerleşmesine yol açması nedeniyle çıkan bu yangın Allah'ın bir gazabı olarak yorumlanmıştır:

Galata ve tevâbi'inde vâki' mahallât-ı müslimîn ve etrâf-ı cevâmi' ve mesâcid mevki'inde(?) kadîmden ehl-i İslâm'ın yedlerinde ve zabt ve tasarruflarında olan hâneleri birer tarîkle keferenin ellerine düşüp mesken ittihâz edinmeleri ile fecere ve fesekanın bu vechile ictimâ‘ı şerâre-feşân-ı celb-i gazab-ı ilâhîye sebeb olur nice ef‘âl-i şenî‘a ve evzâr-ı fazî‘ayı müstetbi‘ olduğundan mâ‘dâ civârlarında olan ehl-i İslâm kâr-ı nâ-hencâr ve kirdâr-ı kabîhat-medârlarından müte'ezzî olup şer'an men'i lâzım ve lâbüd iken hükkâmın müsâmaha ve tegâfülünden nâşî te'hîre kalup ${ }^{45}$

Bunun acilen izale edilmesi için, sonradan gayrimüslimlerin ellerine geçmiş olan yerlerin tekrar Müslümanlara devredilmesi veya satılması gerekmektedir. Sosyal sorunlara neden olabilecek yerlerde meyhane yapılmayacak, kilise ve sinagogların yeniden inşasına da padişah II. Mustafa'nın çıktığı Avusturya Seferi'nden dönene kadar hiçbir şekilde izin verilmeyecektir:

\begin{abstract}
kefere tâ'ifesinin bu makûle yedlerinde bulunan arsalar vakf ise müslimîne îcâr mülk ise ehl-i İslâm'a bey'a icbâr olunup min-ba'd kefere tâ'ifesine binâya müsâ‘ade göstermeyip ve bundan mâ'dâ meyhâneler ve me'vâü'z-zevânî ve büyût-ı ifsâdât olan mahallere min-ba'd binâ olunmaya ve araza-i âfet-i harîk olan Frenk ve Rum ve Yahûd kiliseleri dahi avdet-i sefere değin hâlî üzre kalıp inşaallahüteâlâ avdet-i seferde keyfiyetleri bir hoş keşf ve istıtlâ‘ olundukdan sonra muktezâsına göre amel oluna ${ }^{46}$
\end{abstract}

44 Ahmet Refik, Hicrî On Ikinci Asırda Istanbul Hayatı (1100-1200), (İstanbul: Enderun Kitabevi, 1988), 10-11 (Evh Ca 1104/28 Ocak-7 Şubat 1693); Galata'da Moriskoların 17. yüzyılın başlarında Katolik kiliselerini camiye dönüştürme ve Yahudileri Galata'dan çıkarma girişimlerine dair bkz. Tijana Krstić, "Moriscos in Ottoman Galata, 1609-1620s," Expulsion of the Moriscos from Spain içinde, ed. M. García-Arenal ve G. Wiegers (Leiden: Brill, 2014), 275-77, 283-85; 1612-15 arasında Galata kadısı Molla Ali tarafından başlatılan ve ilgili devletlerle diplomatik krize yol açan 'müstemenlerden cizye alınması' kararına dair bkz. T. Krstić, "Contesting Subjecthood and Sovereignty in Ottoman Galata in the Age of Confessionalization: The Carazo Affair, 1613-1617," Oriente Moderno 93 (2013), 422-53; Krstić, "Moriscos," 278-79; Bu konu ve özellikle Molla Ali hakkında bkz. Baki Tezcan, "Dispelling the Darkness: The politics of 'race' in the early seventeenth century Ottoman Empire in the light of the life and work of Mullah Ali." Identity and Identity Formation in the Ottoman World: A Volume of Essays in Honor of Norman Itzkowitz içinde, ed. Baki Tezcan \& Karl K. Barbir (Madison: University of Wisconsin, 2007), 73-95

45 BOA, MD, 108, 259/1092 (Evs L 1107/13-22 Mayıs 1696).

46 BOA, MD, 108, 280/1185 (Evh L 1107/23 Mayıs-1 Haziran 1696). EK-1. 
Son olarak da ilgililere, "ta'fiye-i münkerât ve te'sîs-i sâlihâtda kemâ-yenbağî dikkat ve ihtimâm" gösterilmesi yani, kötülüğün imhası ve iyiliğin ihyasına, eskiden olduğu gibi ihtimam gösterilmesi uyarısı yapılmıştır.

1700 yılında taklîl-i cemâ‘at meselesi, taraflar arasındaki en önemli ihtilaf konusu olmaya devam etmiştir. Nitekim, Gülnuş Valide Sultan'ın kethüdası olan el-Hac Mehmed Ağa'nın ${ }^{47}$ kadıya sunduğu arzıhalde, yeni yapılan cami etrafında gayrimüslimlerin ev satın aldıkları veya kiraladıkları ve bunun da camide "taklîl-i cemâ'ate sebeb" olduğu belirtilmektedir. Söz konusu gayrimüslimlerin oturdukları yerlerden çıkarılmaları ve evlerin Müslümanların tasarrufuna geçirilmesi gerektiğini öngören bir fetva da arzıhalin fıkhi dayanağını oluşturmaktadır. Buna dair çıkarılan emir şöyledir:

mukaddemâ vâki' olan harîkde muhterik olan ebniyelerin arsalarından hâlâ keferenin tasarrufunda olanlar ba'de'l-yevm yedlerinde kalmayup semen-i misli ile müslimîne bey'i ve ehl-i islâm dahi ol makûle arsalara mâlik olduklarından sonra min-ba'd frenkhâne ve yahûdihâne binâ ettirilmeyip ol makûle câmi'-i şerîfe karîb olan arsalarda ehl-i islâm mütemekkin olmak üzre büyût-ı müslimîn binâ ve cemâ‘at-i müslimînin tevfîr ve teksîrine kemâ-yenbağî tekayyüd ve ihtimâm olunmak bâbında hükm-i hümâyûnum recâ etmeğin vech-i meşrûh üzre amel oluna deyû yazılmışdır ${ }^{48}$

Yeni Cami çevresinde Müslüman nüfusun artırılmasına özen gösterilirken bir taraftan da gayrimüslimler açısından başka sorunlar ortaya çıkmıştır. 1710 tarihli “Bende ahâlî-i mahalle fukarâları" imzalı arzıhal, Yeni Cami inşasıyla daha da belirginleşen ihraç ve iskân geriliminin sosyal, psikolojik ve ekonomik yönünü yansıtmaktadır. Buna göre, fetihten beri Arap Camii çevresinde Müslümanların oturduğu fakat zamanla ve yangın sonrasındaki duruma bağlı olarak bazı yetkili kişilerin de müsamaha ve müsaadesi ile kimi arsalar gayrimüslimlerin mülkiyet ve tasarruflarına geçmiştir. Hacı Osman isminde birisinin Arap Camii'ne bakan mülk arsasını bir Fransız'a sattığı ve onun da buraya ev yapmaya başladığı örnek gösterilmiştir. Söz konusu Fransız'ın ev yapma iznini almasının arkasında, arzıhal sahiplerinin "taraf-gîr" olarak tanımladıkları Galata kadııı ve başka bazı kimselerin desteği bulunmaktadır. Arap Camii ve Yeni Cami çevresinde halihazırda gayrimüslimlerin oturdukları ev sayısı 15 kadardır. Bunların da 11'i bazı devlet adamlarına aittir. Daha önce gayrimüslimler bu bölgeden defaatle ihraç edilmiş olsalar da istenen sonuç elde edilememiş ve durum tersine dönmüştür. Bunda, gayrimüslimlerden yüksek kira alan ev sahiplerinin tamahkâr tutumları etkili olmuştur. Son tahlilde, Müslümanlara verdikleri rahatsızlık nedeniyle gayrimüslimlerin bu evlerden çıka-

47 Kürd Mehmed Ağa, Saray-ı Atîk teberdarlarından olup bu göreve 19 Receb 1106/5 Mart 1695 tarihinde getirilmiş ve yirmi yıl süreyle Valide Gülnuş Emetullah Sultan'a kethüdalık yapmıştı. Silâhdar, Nusretnâme, 89; Ayrıntılı bilgi için bkz. İpşirli Argıt, Rabia Gülnuş, 55.

48 Refik, Hicrî On İkinci, 30-31 (Evh S 1112/7-17 Ağustos 1700). 
rılmaları gerekmektedir. Arzıhal sahiplerine göre, Mesleme b. Abdülmelik'in şefaatine nail olmanın yolu buradan geçmektedir:

tâife-i mezbûrenin bir tarafı devletlü Vâlide Sultan efendimiz hazretlerinin Câmi'-i şerîfi ve bir cânibi Arab Câmi'-i şerîfi bu iki ma'bed-i kadîmelerin beynlerinde ancak on beş kadar Nasrânî menzillerde sâkinler olup menâzil-i mezbûrenin on biri Devlet-i Aliyye ricâllerinden ba'zı kimesnelerin mülkleri olup lâkin kendüleri sâkin olmayıp Nasârâ tâifesine tama'-ı hâmları sebebiyle ziyâde icâre ile istîcâr etmişlerdir ve menâzil-i mezbûrelerden tâife-i merkûmeleri nice def'a ihrâc olunup min-ba'd bir dahi iskân eylememek üzre yedimize iki kıt'a hüccet-i kâtı'a verilmiş iken manzûr-ı hümâyûnları merhamet buyurulur ise mûcebince merkûmları ihrâc ve yerlerine Müslimîn iskân ve ba'de'l-yevm mahalle-i merkûme hudûdu dâhilinde Yahûd ve Nasârâ iskân etdirilmemek bâbında merhamet ve ma‘bed-i kadîmenin dâmenin küffâr-ı bed-fa‘âlin destinden halâs ve bânîsi olan güzîde-i tâbi'înden Mesleme hazretlerinin şefâ‘at-i şerîfelerine mazhar olunmağa bâ‘is ... ${ }^{49}$

Bu arzıhal üzerine, hukuk bilgisine güvendiği bir naip ataması, civar mahalle sakinlerinden durumun sorulması ve etraflı bir inceleme yaptırması için İstanbul kadısına emir verilmiştir:

İstanbul kadısı fazîletlü efendi tarafınızdan bir mütedeyyin ve müteşerri' nâib ta‘yîn edip ta'yîn olunan mübâşir ma'rifetiyle mahall-i merkûma irsâl ve hem-civârları olan ve sâ'ir bî-garaz Müslimînden tefahhus ve su'âl ve mukaddemâ yedlerine men'i için verilen hüccet-i şer'iyyelere mugâyir ve muhâlif ise ma'rifet-i şer'le görüp sıhhati üzere i'lâm eylemek üzre muhkem tenbîh eyliyesiz deyû buyruldu ${ }^{50}$

Naip olarak görevlendirilen müderris Mehmed Efendi'nin ilâmına bakıldığında, Arap Camii'ne komşu mahallelerden imam, cemaat ve ihtiyarlardan (seçilmiş kimseler) iki yüzden fazla kişiden oluşan heyet (cemm-i gafîr ve cem'-i kesîr) ile konu, yerinde soruşturulmuştur. Söz konusu evlerin 16 tane olduğu, yangından sonra bu evlerin teker teker gayrimüslimlere kiralandığı veya satıldığı anlaşı ımıştır. Bu kimselerin, camiye gidip gelen Müslümanları rahatsız etmeleri nedeniyle "taklîl-i cemâ‘ate" neden oldukları da ayrıca belirtilmiştir.

işbu Saatçi Arlovario ve Yako ve Fransız ve Nikola ve Üngürüs ve diğer Fransız ve Saatçi Dona ve İsrail ve Fransız Derzi ve diğer Fransız nâm müste'menler ve Sakızlı ve diğer Sakızlı kefere ve Avram ve Abram ve Mosi nâm Yahûdiler sâkin oldukları on altı aded menâzil, kadîmden Müslimîn menzilleri olup bundan akdem kirâren ve mirâren Müslimîn iskân olunmuşiken

49 GSSS, 206, 87 (4 Ca [11]22/2 Temmuz 1710). EK-2.

50 GŞS, 206, 87 (4 Ca [11]22/2 Temmuz 1710). EK-2. 
zikr olunan menâzil harîkde muhterik olmağla tedrîc ile ba'zıları temellük ve ba'zıları istîcâr edip bi'l-cümle menâzil-i mezkûrede kefere ve Yahûd tâifesi sâkinler olup leyl ü nehâr âlât-ı harble gezip ve nice ümmet-i Muhammed'in başlarına dükürüp ve şarâb döküp Câmi'-i şerîfe gidenleri istihfâf ve istihzâ edip ve envâ‘'ı şekāvet ve fesâdât ve şenâ'at ve âyîn-i bâtılların icrâ etmeleriyle cemâ'at-i Müslimîn havf ve haşyetlerinden gece ile taşra ve Câmi'-i şerîfe çıkmakdan kaldıklarından ma'dâ taklîl-i cemâ‘ate dahi bâ'is ve mü’eddî olduklarını ${ }^{51}$

İstanbul kadılığından gelen bu ilâm üzerine, isimleri belirtilen gayrimüslimlerin evlerden çıkarılması emri gönderilmiştir. ${ }^{52}$

Gelişen bu olaylar karşısında Fransız ${ }^{53}$ elçisi Pierre Punchot ${ }^{54}$ harekete geçerek Padişaha bir arzıhal sunmuştur. Elçinin belirttiğine göre, Arap Camii çevresinde üç yüzden fazla Müslüman hanesi olup, eskiden beri burada sakin olan “Efrenc taifesi”nin hiçbir şekilde taklîl-i cemaate sebep olmaları mümkün değildir. Kötü niyetli bazı kimseler konuya dair yanlış bilgiler vermiş, başka mahallelerden adam toplanarak şikâyetler delillendirilmeye çalışılmış, İstanbul kadısı da onların lehinde ilâm hazırlayarak evlerin boşaltılması hükmünü vermiştir. Fakat bu iddialar gerçek dışıdır. Hatta, gayrimüslimlerin taklîl-i cemaate sebep olmadıkları şeyhülislâm fetvası ile sabittir.

Sözü geçen fetvaya göre ilâmda bulunması için İstanbul kadısına emir yazılmışsa da elçi Puchot, İstanbul kadısının daha önce aleyhte verdiği kararından dolayı davanın Anadolu kazaskerine havalesini istemiştir. Gayrimüslimlerin dört, beş ay önce boşalttıkları evlerin halen boş durmasına bakılırsa, Elçi'ye göre, camilerde herhangi bir şekilde "taklîl-i cemaat" sorunu da söz konusu değildir. Elçi, verdiği arzıhalde sıraladığı gerekçelerle Frenklerin geri dönmelerine izin verilmesini talep etmektedir. ${ }^{55}$

51 GŞS, 206, 87 (4 Ca 1122/2 Temmuz 1710). EK-2.

52 GŞS, 206, 87 (Ca 1122/Temmuz 1710). EK-2.

53 Kutsal İttifak içinde yer alması dolayısıyla Venedik elçisinin bulunmadığı Galata'da Katoliklerin hamisi bu dönemde Fransa'ydı. 1585'te ibadete kapatılan San Françesko Kilisesi, Fransa elçisi Savary de Brèves'in çabaları ile 1597 yılında tekrar ibadete açılmıştır. Bunun bir sonucu olarak Galata'daki Katolik kiliseleri Fransa'nın hamiliğini kabul etmişlerdi. Bkz. Frazee, Catholics, 79 vd.; 1608 yilında ise Fransa, Galatalılar tarafından "protecteur generale [genel hami]" olarak tanınd. Bkz. Dursteler, İstanbul'daki Venedikliler, 220'den naklen A. Trannoy, "La "nation latine" de Constantinople," Échos d'orient 11 (1912), 252; Ayrıca, 1685-1719 arasında 175 Fransız Galata'ya gelerek yerleşmiştir. Bkz. Robert Mantran, 17. Yüzyılın Ikinci Yarısında İstanbul, 1, çev. M. Ali Kııı̧bay, Enver Özcan (İstanbul: V Yayınları, 1986), 76; Özellikle, 1695'te Venedik'ten alınan Sakız Adası'nda da Katoliklik yasaklanmış, soylulardan dört kişi idam edilmiş, Rum-Ortodoksluk serbest bırakılmış, Katolik katedrali camiye dönüştürülmüş, diğer kiliseler ise ya kapatılmış ya Rumlara verilmiş veya yıkıımıştır. J. Wihelm Zinkeisen, Osmanlı Imparatorluğu Tarihi: (1669-1774) (Istanbul: Yeditepe Yayınevi, 2011), 126-7; Katoliklerin imtiyazlarının kaldıııldı̆ı Sakız Adası'nda sadece Fransız Konsolosluğu dahilinde bulunan Katolik kilisesine dokunulmamıştır. bkz. Ali Fuat Örenç, "Sakız Adası," DiA 36 (2009), 7.

54 Alleurs Markizi P. Punchot (Marques des Alleurs), 1710-1716 yılları arasında İstanbul'da elçilik yapmıştır. Biyografisi için bkz. Jean-Louis Bacqué-Grammont, Sinan Kuneralp, Frédéric Hitzel, Représentants Permanents de la France en Turquie (1536-1991) et de la Turquie e France (1797-1991), (Istanbul-Paris: ISIS Édition, 1991), 27-8.

55 GŞS, 208, 66b (L 1122/Kasım-Aralık 1710). EK-3. 
mezbûrların iddi'âları hilâf-ı şer‘ olduğuna Şeyhülislâm -sellemehü’s-selâm- hazretlerinden fetvâ-yı şerîfe ihsân olduğunu huzûr-ı sa'âdete arzıhâl eylediğimizde İstanbul kadısı fazîletlü efendi yedlerinde olan fetvâ-yı şerîfesi mûcebince husûs-ı mezbûru görüp i'lâm eyliyesiz deyû fermân-ı şerîfleri ihsân olunup lâkin İstanbul efendisi mukaddemâ ahâlî-i mahalle-i merkûmenin yedlerine Efrenc tâifesinin aleyhine ve ihrâclarıçün i'lâm vermekle sa'âdetlü sultânım hazretlerinden mercûdur ki Anadolu kazaskeri fazîletlü efendi hazretleri mevlânâ nasb ve ta'yîn buyurulup Galata'da ahâlî-i mahalleden su'âl ve Efrenc tâ'ifelerinin hâneleri hâlâ boş olup bir vecihle taklîl-i cemâ'ate bâ'is olmadığı ma'lûm-ı devletleri oldukda ol ehl-i garaz kimesnelerin te'addîleri men've ke'l-evvel Efrenc tâ'ifesi sâkin oldukları hânelerde sâkinler olmak bâbında fermân-ı şerîf insân buyurula ${ }^{56}$

Bu arzıhal üzerine yazılan buyruldu tam da elçinin istediği şekilde olmuş, yalnız bu kimselerin Müslümanları hiçbir şekilde rahatsız etmemeleri özellikle vurgulanmıştır:

Sadr-I Anadolu izzetlü fazîletlü efendi hazretleri sâhib-i arzıhâl Efrenc tâ'ifesinin yedlerinde olan Galata kadısının i'lâmı mûcebince ahâlî-i mahallenin rızâlarıyla ta'yîn olunan mübâşir ağa ma'rifetiyle hânelerinde iskân olunup Müslimîne te‘addîleri ve istihfâfları olmamak üzre muhkem tenbîh oluna deyû buyruldu ${ }^{57}$

1713 yılının başlarında şikâyetlerini Divan'a taşıyanlar bu defa Galatalı Müslümanlardı. "Bendegān-ı fukarā-yı Galata" imzalı arzıhallerinde Müslümanlar, Arap Camii çevresindeki bazı evlerin gayrimüslimlerin elinde olmasının "taklîl-i cemâ‘ate bâ‘is" olduğuna dikkat çekmektedirler. İki yı önce gayrimüslimler bu evlerden çıkarılmış olsalar da, ${ }^{58}$ bazı ev sahiplerinin karşı davaları ile durum tersine dönmüştür. Nüfuzlarını kullanan bu kimseler, evlerin tasarım açısından Müslümanlar için elverişli olmaması ve gayrimüslimlere uygulanan oturma yasağı nedeniyle kiracı bulamadıkları için maddi zarara uğradıklarını ifade ederek gayrimüslimlerin burada tekrar iskân edilmelerinin yolunu açmışlardır. Bundan muzdarip olsalar da herhangi bir şey yapamayan Galata Müslümanlarının imdadına, çıkan son yangın ${ }^{59}$ yetişmiş ve tartışma konusu olan evler yanmıştır. Bunun üzerine, ev sahiplerinin iki yıl önceki beyanlarına ek olarak gayrimüslimlerin ihracını gerektiren hüccetlere istinaden belli bir sınır dahilinde gayrimüslim iskânının yasaklanmasını talep etmişlerdir:

56 GŞS, 208, 66b (L 1122/Kasım-Aralık 1710). EK-3.

57 GŞS, 208, 66b (13 L 1122/5 Aralık 1710); Elçi Puchot, başarısının bir ispatı olan söz konusu buyruldunun bir tercümesini raporuna ekleyerek Paris'e ulaştırmıştır. Bkz. İlber Ortaylı, “Galata," DiA 13 (1996), 306'dan naklen Archives des affaires étrangères, C. P. Turquie, LI, 17 Mayıs 1711 tarihli rapor, 25 vd.

58 İlgili belge için bkz. GŞS, 206, 87 (Ca 1122/Temmuz 1710).

59 1710-1713 yılları arasında çıkmış olduğu anlaşılan bir yangın. 
menzil-i mezbûrlardan kefere ve yahûd ihrâc olunmuşlar iken tekrâr sadr-ı a'zam-ı sâbık Mehmed Paşa vezâretinde menzil-i mezbûrların sâhibleri bizim menzillerimizde ancak yahûd ve efrenc sâkin olur ümmet-i Muhammed sâkin olmak mümkün değildir menzillerimiz mu'attal ve bizlere küllî gadr olmuşdur deyû birer tarîkle istîzân edip kemâ fi'l-evvel yerlerine gelip sâkin olduklarından tekrâr nizâ' olunmak üzre iken bu def'a Galata'[da] vâki' harîk-i azîmde zikr olunan menziller bi'l-külliye muhterik olup eser-i binâsı kalmamağla menzil-i mezbûrların sâhibleri bizim hânelerimize efrenc ve yahûd sâkin olmak için binâ olunmuş yohsa biz dahi Câmi'-i şerîfe karîb kefere ve yahûd olduğun istemeziz deyû iddi'âları üzre el-yevm yedlerimizde olan hücec-i şer'iyyeler mûcebince tahdîd-i hudûd dâhilinde min-ba'd kefere ve yahûd sâkin olmamak üzre ${ }^{60}$

Netice olarak, Müslümanların bekledikleri karar çıkmış ve gayrimüslimlere bu civarda oturma yasağı getirilmiştir:

Yedlerinde olan hüccet-i şer'iyyeler mûcebince tahrîr olunan hudûd dâhilinde fîmâ-ba'd kefere ve yahûd hâne yeri binâ olunmayıp ehl-i İslâm'a mahsûs menziller binâ olunup ehl-i İslâm sâkin ve hilâfından hazer oluna deyû buyruldu'b1

Müslümanların konu ile ilgili takiplerini ısrarla devam ettirdikleri, aynı yıl İstanbul kaymakamı ve Galata kadısına gönderilen fermandan anlaşılmaktadır. Buna göre, Hacı Hüseyin ve Bahri Hatun ile onlara destek olan İsrail ve Musa isimli iki Yahudi, yapılan üç ayrı uyarıyı dikkate almamışlar ve kâr etme güdüsü ile Arap Camii ve Yeni Cami arasında gayrimüslim evleri bina etmişlerdir. Bu evleri almak, kiralamak isteyen Müslümanlara da hiçbir şekilde olumlu karşılık vermemişlerdir:

Hacı Hüseyin nâm kimesne ile Bahri nâm hâtun yahudi tâ'ifesinden İsrail ve Musa nâm yahudiler ile müttefiki tama'-ı hâma düşüp kefere ve yahudi tâ'ifesiçün mahsûs menziller binâ etmeleriyle ... Vâlidem Sultan medîne-i Galata'da binâ ve ihyâ buyurdukları Câmi'-i şerîf ile Arap Câmi'[i] beyninde kefere ve yahûd olmamak üzre yedlerinde olan emr-i şerîfim mûcebince cânib-i şer'den üç def'a tenbîh olundukda mütenebbih ve itâ‘at etmeyip ve binâ eyledikleri menzilleri dahi müslimînden tâlib olanlara vermeyip ihânet ve cemâ‘at-i müslimîn müte'ezzî oldukların bildirip yedlerinde olan hüccet-i şer'iyyeleri mûcebince kefere ve yahûdi tâ'ifesinin telvîsâtından halâs olunmak bâbında hükm-i hümâyûnum recâ eyledikleri ecilden ${ }^{62}$

60 GŞS, 219, 94b/1 (Z 1124/Ocak 1713). EK-4.

61 GŞS, 219, 94b/1 (27 Z 1124/25 Ocak 1713). EK-4.

62 GŞS, 219, 94a/1 (Evh Ca 1125/14-24 Haziran 1713). EK-5. 
Yapılan bu tespitlerin bir gereği olarak, belirlenen sınırlar içinde Müslüman evlerinin yapılması emredilirken, gayrimüslim iskânına da yasak getirilmiştir:

hüccet-i şer'iyyeler mûcebince tahdîd olunan hudûd dâhilinde fîmâ-ba'd kefere ve yahûdi hânesi binâ olunmayıp ve iskân etdirilmeyip ehl-i İslâm'a mahsus menziller binâ olunup ehl-i İslâm sâkin olup hilâfından hazer olunmak bâbında fermân ${ }^{63}$

\section{Sonuç}

İspanya'dan göçmüş ve Arap Camii çevresinde iskân edilmiş olan Müslümanların gayrimüslimlere karşı katı tavırlarında İspanya'da Katoliklerden gördükleri muamele etkili olmuş olmalıdır. Zira bu etkinin bir sonucu olarak 17. yüzyılın başından sonuna kadar Galata'da, Müslüman ile gayrimüslimler özellikle de Katolikler arasında sürekli bir gerilim hattı olagelmiştir. Yüzyılın sonlarında Osmanlılar karşısında Avrupa'da oluşturulan Kutsal İttifak ise, toplumsal psikoloji ve dolayısıyla reaksiyonu belirlemiştir. Venedik'in bu koalisyon içinde bulunması, özellikle Katoliklere karşı tepki doğurmuş ve bunun bir göstergesi olarak, Galata'nın en önemli kilisesi olan San Françesko Kilisesi, Valide Sultan adına camiye dönüştürülmüştür. Hukuki gerekçeleri şekli açıdan tutarlı olsa da bunun Venedik'e bir mesaj olarak tasarlandığı tahmin edilebilir.

Müslümanların, Katolikleri Arap Camii ve Yeni Valide Camii çevresinden ihraç ettirmek için başvurdukları özellikle "taklîl-i cemâ‘at" gerekçesi makul ve meşru bulunabilir. Nitekim, mahkemenin ilâmı doğrultusunda divanın verdiği karar lehte olmuştur. Ancak, daha sonra Fransız elçisinin de gerekçelerini sıralayarak Katoliklere haklarının geri verilmesini talep etmiş olması, taraflar arasındaki iskân tartışmasının yukarıda değinilen hassas ortamda cereyan ettiğini düşündürmektedir. Hatta, elçinin redd-i hâkim talebi üzerine davanın İstanbul kadısına değil Anadolu kazaskerine havale edilmesi ile kararın, her ne kadar ondan üç yıl sonra tekrar aleyhlerine dönecek olsa da, Katolikler lehine şekillenmiş olması bu düşünceyi destekler mahiyettedir.

Bütün bu etkileşim ve dönüşümler her ne kadar toplumsal, siyasi, dinî bir arka plana sahip olsa da, her uygulamanın hukuka dayandırıması bir zorunluluktu. Bu açıdan, Müslüman ve Katolikler arasında yaşanan iskân tartışması, bir hukuk mücadelesi görünümündedir. Süregiden bu tartışmanın karşııklı olarak mahkemeye taşınması ise, Osmanlı hukukunun kendi içinde dengeleyici özelliğini göstermektedir. Nitekim, birbirini nakzeden kararların alınabilmesi ve bir yabancı elçinin redd-i hâkim talebine divanın olumlu karşılık vermiş olması, bu şekilde yorumlanabilir. Davanın kesin çözüme bir türlü kavuşturulamaması, taraflar arasında yıllara yayılan bir gündemi teşkil etmesi hatta, uluslararası bir nitelik kazanması ise, toplumsal refleksin dinî ve siyasi yönleri hakkında fikir vermektedir. 
Sonuç olarak, cami inşası, mabet dönüştürmeleri ve iskân ile Galata'ya Müslüman bir görünüm kazandırma düşüncesi zaman zaman kendini göstermiştir. Ancak, bu süreçler toplum temelinde ciddi gerilimlerin yaşanmasına da sebebiyet vermiş̧tir. ${ }^{64}$ Nitekim, henüz Müslümanlar ve gayrimüslimler arasında yaşanmış, 1693'te Arap Camii çevresinde başlayıp 1696'da Yeni Cami'nin inşasıyla alevlenen bir iskân tartışmasının 1713'e ve belki daha ileriki yıllara kadar devam etmiş olması, Galata'daki bu dönüşümlerin maddi ve psikolojik ağırlığına dair fikir vermektedir.

Hakem Değerlendirmesi: Dış bağımsız.

Çıkar Çatışması: Yazar çıkar çatışması bildirmemiştir.

Finansal Destek: Yazar bu çalışma için finansal destek almadığını beyan etmiştir.

Teşekkür: İtalyanca kaynakları kullanmamda yardımcı olan Tommaso Stefini'ye, makale ile ilgili değerli görüşlerini paylaşan ve destek olan Vanessa de Obaldia ve Emrah Safa Gürkan'a teşekkür ederim.

Peer-review: Externally peer-reviewed.

Conflict of Interest: The author has no conflict of interest to declare.

Grant Support: The author declared that this study has received no financial support.

Acknowledgement: I would like to thank Tommaso Stefini who helped me to use the Italian resources, Vanessa de Obaldia and Emrah Safa Gürkan for sharing their valuable opinions and support about the article.

\section{Bibliyografya/Bibliography}

\section{Arşiv Belgeleri/ Archive Documents}

Galata Şeriyye Sicilleri (GŞS) no: 171, 174, 206, 208, 219.

Başkanlık Osmanlı Arşivi, Mühimme Defteri (BOA, MD), no: 108.

\section{Makale ve Kitaplar/ Articles and Books}

“Tarih-i Nihâdî (152b-233a) (transkripsiyon ve değerlendirme).” haz. Hande Nalan Özkasap. Yüksek Lisans Tezi, Marmara Üniversitesi, 2004.

Akyıldız, Ali. Haremin Padişahı Valide Sultan: Harem'de Hayat ve Teşkilat. İstanbul: Timaş, 2017.

Andreasyan, Hrand D. “Eremya Çelebi'nin Yangınlar Tarihi.” Tarih Dergisi 27 (1973): 59-84.

Arseven, Celal Esad. Eski Galata ve Binâları. ed. Dilek Yelkenci. İstanbul: Çelik Gülersoy Vakfı Yay., 1989.

Ayvansarâyî, Hâfız Hüseyin. Hadîkatü'l-Cevâmi' (İstanbul Câmileri ve Diğer Dînî-Sivil Mi'mârî̀ Yapılar). ed. Ahmed Nezih Galitekin. İstanbul: İşaret, 2001.

Bacqué-Grammont, Jean-Louis, Sinan Kuneralp, Frédéric Hitzel. Représentants Permanents de la France en Turquie (1536-1991) et de la Turquie e France (1797-1991). İstanbul-Paris: ISIS Édition, 1991.

Baer, Marc David. IV. Mehmet Döneminde Osmanlı Avrupası'nda Ihtida ve Fetih. çev. Ahmet Fethi. İstanbul: Hil Yayın, 2009.

64 Genel manzarayı yansıtan bilgiler için bkz. Eldem, “Ottoman Galata," 19-36. 
Belin, M. A. Histoire de la Latinité de Constantinople. $2^{e}$ ed., revue, augmentée et continuée jusqu'a notre temps par Le R. P. Arséne de Chatel. Paris: A. Picard, 1894.

Berksan, Emine. “II. Mustafa ve III. Ahmed'in Valideleri Emetullah Gülnûş Sultan ve Vakıfları.” Yüksek Lisans Tezi, İstanbul Üniversitesi, 1998.

Bulunur, Kerim Ilker. “II. Mehmed tarafından Galatalılara Verilen 1453 Ahidnâmesi ve Buna Yapılan Eklemeler Hakkında Yeni Bilgiler." Tarih Dergisi 50 (2009/2): 59-85.

Bulunur, Kerim İlker. Osmanlı Galatası [1 453-1600]. İstanbul: Bilge Kültür Sanat, 2014.

Çetinkaya, Halûk. “Arap Camii in Istanbul: its Architecture and Frescoes." Anatolia Antiqua 18 (2010): 169-88.

Dauverd, Céline. "Cultivating Differences: Genoese Trade Identity in the Constantinople of Sultan Mehmed II, 1453-81." Mediterranean Studies, Special Issue: The Mediterranean Voyage, 23/2 (2015): 94-124.

de La Motraye, Aubry. La Motraye Seyahatnamesi. çev. Nedim Demirtaş. İstanbul: İstiklal Kitabevi, 2007.

Defterdar Sarı Mehmed Paşa. Zübde-i Vekayiât: Tahlil ve Metin (1066-1116 / 1656-1704). haz. Abdülkadir Özcan. Ankara: Türk Tarih Kurumu, 1995.

Dursteler, Eric R. İstanbul'daki Venedikliler: Yeniçağ Başlarında Akdeniz'de Millet, Kimlik ve Bir Arada Varoluş. çev. Taciser Ulaş Belge. İstanbul: T. İş Bankası, 2012.

Eldem, Edhem. "Ottoman Galata and Pera Between Myhth and Reality." From "milieu de memoire" to "lieu de memoire" içinde 19-36. ed. Ulrike Tischler. Münhcen: Martin Meidenbauer, 2006.

Evliya Çelebi. Seyahatnâme, I. haz. O. Şâik Gökyay. İstanbul: YKY, 1996.

Eyice, Semavi. “Arap Camii.” DIA 3 (1991): 326-27.

Frazee, Charles A. Catholics and Sultans: The Church and the Ottoman Empire 1453-1923. Cambridge : Cambridge University, 2006.

Girardelli, Paolo. "Architecture, Identity, and Liminality: On the Use and Meaning of Catholic Spaces in Late Ottoman Istanbul." Muqarnas 22 (2005): 233-64.

Güler, Mustafa. Gülnûş Vâlide Sultan'ın Hayatı ve Hayrâtı I. İstanbul: Çamlıca, 2006.

Gülsoy, Ersin. Girit'in Fethi ve Osmanlı İdaresinin Kurulması (1645-1670). İstanbul: TATAV, 2004.

Hoci, İskender Yanko. “Galata'nın Osmanlılara Teslîmi.” Tarih-i Osmani Encümeni Mecmuası 5/25 (1330): 49-53.

İnalcık, Halil. "Ottoman Galata." Essays in Ottoman History içinde 275-376. İstanbul: Eren Yayıncılık, 1998. İpşirli Argıt, Betül. Rabia Gülnuş Emetullah Sultan (1640-1715). İstanbul: Kitap Yayınevi, 2014.

İpşirli, Mehmet. “Gülnûş Emetullah Sultan”. DiA 14 (1996): 248-49.

Krstić, Tijana. "Contesting Subjecthood and Sovereignty in Ottoman Galata in the Age of Confessionalization: The Carazo Affair, 1613-1617". Oriente Moderno 93 (2013): 422-53.

Krstić, Tijana. "Moriscos in Ottoman Galata, 1609-1620s." Expulsion of the Moriscos from Spain içinde 269-85. ed. M. García-Arenal and G. Wiegers, Leiden: Brill, 2014.

Mantran, Robert. 17. Yüzyılın İkinci Yarısında İstanbul, 1. çev. M. Ali Kılıçbay ve Enver Özcan. İstanbul: V Yayınları, 1986.

Marmara, Rinaldo. Bizans'tan Günümüze İstanbul Latin Cemaati ve Kilisesi. Çeviren: Saadet Özen. İstanbul: Kitap Yayınevi, 2006.

Matteucci, Gualberto. Un Glorioso Convento Francescano sulle rive del Bosforo: il S. Francesco di Galata in Constantinopoli. Firenze: Edizioni Studi Francescani, 1967.

Mitler, Louis. "The Genoese in Galata: 1453-1682." International Journal of Middle East Studies 10/1 (1979): 71-91. 
Müller-Wiener, Wolfgang. İstanbul'un Tarihsel Topografyası: 17. Yüzyıl Başlarına Kadar ByzantionKonstantinopolis-İstanbul. Çeviren Ülker Sayın. İstanbul: YKY, 2001.

Obaldía, Vanessa R. de. "A Shared Space and Shared Functions: From a Latin Catholic Church to an Islamic Vakıf in Ottoman Galata." Endowment Studies 2/2 (2018): 133-62.

Ortaylı, ilber. “Galata”. DIA 13 (1996): 303-307.

Örenç, Ali Fuat. “Sakız Adası.” DiA 36 (2008): 6-10.

Özcan, Abdülkadir. “ístanbul'un Eminönü Semti XVII. Yüzyılda mı İslâmlaştırıldı?.” Osmanlı Araştırmaları 37 (2011): 206-213.

Özdemir, Mehmet. “Moriskolar." DIA 30 (2005): 288-91.

Özgüleş, Muzaffer. “Gülnuş Emetullah Sultan'ın İmar Faaliyetleri.” Doktora Tezi, İstanbul Teknik Üniversitesi, 2013.

Özgüleş, Muzaffer. The Women Who Built the Ottoman World: Female Patronage and the Architectural Legacy of Gülnuş Sultan. London and New York: I. B. Tauris, 2017.

Palazzo, P. Benedetto, O. P. Arap Camii veya Galata Saint Paul Kilisesi. çev. İ. Burhan Yentürk. İstanbul: Bilge Karınca Yayınları, 2014.

Refik, Ahmet. Hicrî On İkinci Asırda Istanbul Hayatı (1100-1200). İstanbul: Enderun Kitabevi, 1988.

Silahdar Fındıklıı Mehmed Ağa. "Zeyl-i Fezleke (1065-22 Ca.1106 / 1654-7 Şubat 1695): Tahlil ve Metin." Haz: Nazire Karaçay Türkal. Doktora Tezi, Marmara Üniversitesi, 2012.

Silâhdar Fındıklıı Mehmed Ağa. Silâhdar Fındıklıı Mehmed Ağa Nusretnâme: Inceleme - Metin (11061133/1695-1721). haz. Mehmet Topal. Ankara: Türkiye Bilimler Akademisi, 2018.

Söyler, Olgay. "Bizans-Arap Savaşları Gölgesinde Arap Camisi veya Galata Aziz Paulus Kilisesi." Vakıf Restorasyon Yıllı̆̆ı 16 (2018): 80-87.

Şakiroğlu, Mahmut H. "Fatih Sultan Mehmet'in Galatalılara Verdiği Fermanın Türkçe Metinleri." Tarih Araştırmaları Dergisi 14/25 (1981-1982): 211-24.

Şeker, Cengiz (ed.). Fatih Sultan Mehmed Vakfiyeleri. Ankara: Başbakanlık Vakıflar Genel Müdürlüğü İstanbul: Çamlıca Kültür ve Yardım Vakfı, t.y.

Tezcan, Baki. “Dispelling the Darkness: The politics of 'race' in the early seventeenth century Ottoman Empire in the light of the life and work of Mullah Ali." Identity and Identity Formation in the Ottoman World: A Volume of Essays in Honor of Norman Itzkowitz içinde 73-95. ed. Baki Tezcan \& Karl K. Barbir, Madison: University of Wisconsin, 2007.

Tournefort, Joseph de. Tournefort Seyahatnamesi. II. Kitap, ed. Stefanos Yerasimos. Çeviren Teoman Tunçdoğan. İstanbul: Kitap Yayınevi, 2005.

Uluçay, M. Çağatay. Padişahların Kadınları ve Kızları, 2. bs. Ankara: Türk Tarih Kurumu, 1985.

Yıldız, Kenan. 1660 İstanbul Yangını ve Etkileri: Vakıflar, Toplum ve Ekonomi. Ankara: Türk Tarih Kurumu, 2017.

Yıldız, Kenan. “Doğruluğu Tartışmalı Bir Tartışma: 1660 Yangını İstanbul'un İslâmlaşmasına Etki Etti mi?." Osmanlı İstanbulu Uluslararası Sempozyum-I (29 Mayıs - 1 Haziran 2013) içinde 197-242. ed. Feridun M. Emecen, Ali Akyıldız, Emrah Safa Gürkan, İstanbul: İstanbul 29 Mayıs Üniversitesi 2014.

Zarinebaf, Fariba. Mediterranean Encounters: Trade and Pluralism in Early Modern Galata. Oakland, California: University of California Press, 2018.

Zinkeisen, J. Wihelm. Osmanlı Imparatorluğu tarihi: (1669-1774). İstanbul: Yeditepe, 2011. 


\section{EKLER}

EK-1: Sonradan gayrimüslimlerin ellerine geçmiş olan yerlerin tekrar Müslümanlara devredilmesi veya satılmasına dair ferman. BOA, MD, 108, 280/1185 (Evh L 1107/23 Mayıs-1 Haziran 1696)

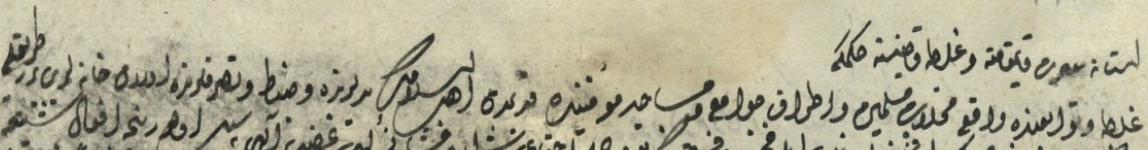
فن (s)

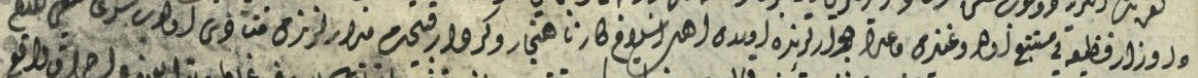

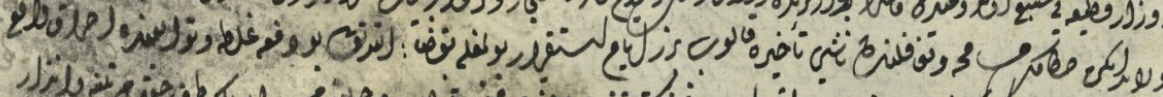

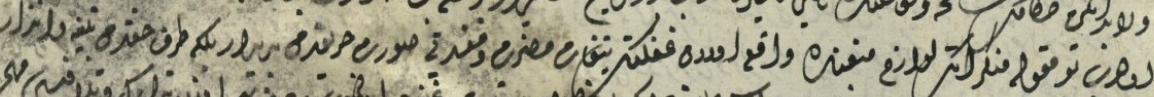

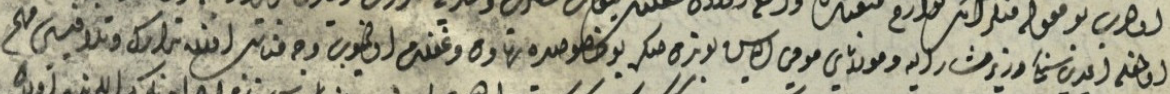

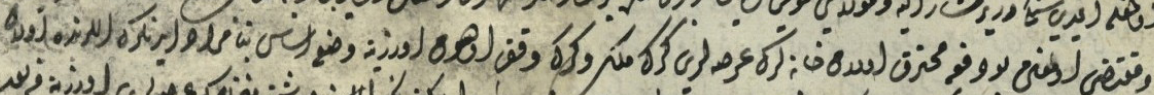

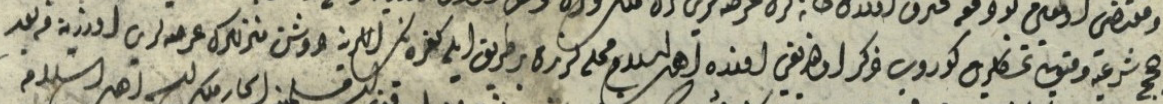

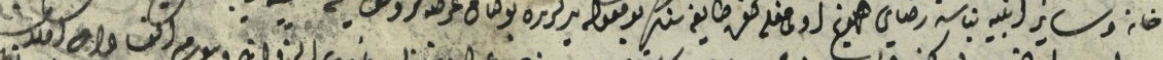

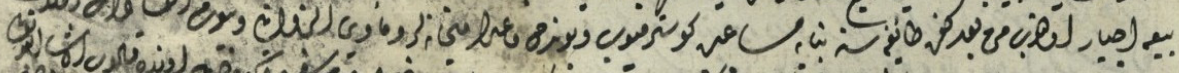

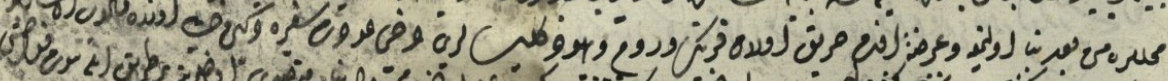
c

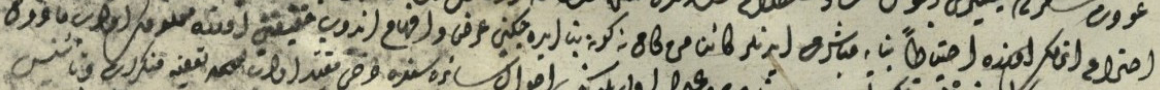

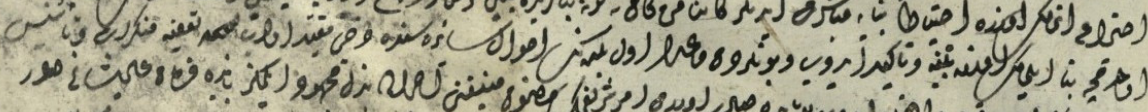
igiel2 rili (pib) 
Bitmeyen Bir İskân Tartışması: Galata'da Yeni Valide ve Arap Camileri Etrafında Katolik - Müslüman...

EK-2: Arap Camii ve Yeni Cami çevresindeki 15 gayrimüslim hanesinin Müslümanlara devredilmesini talep eden arzıhal. GŞS, 206, 87 (4 Ca [1 1]22/2 Temmuz 1710)

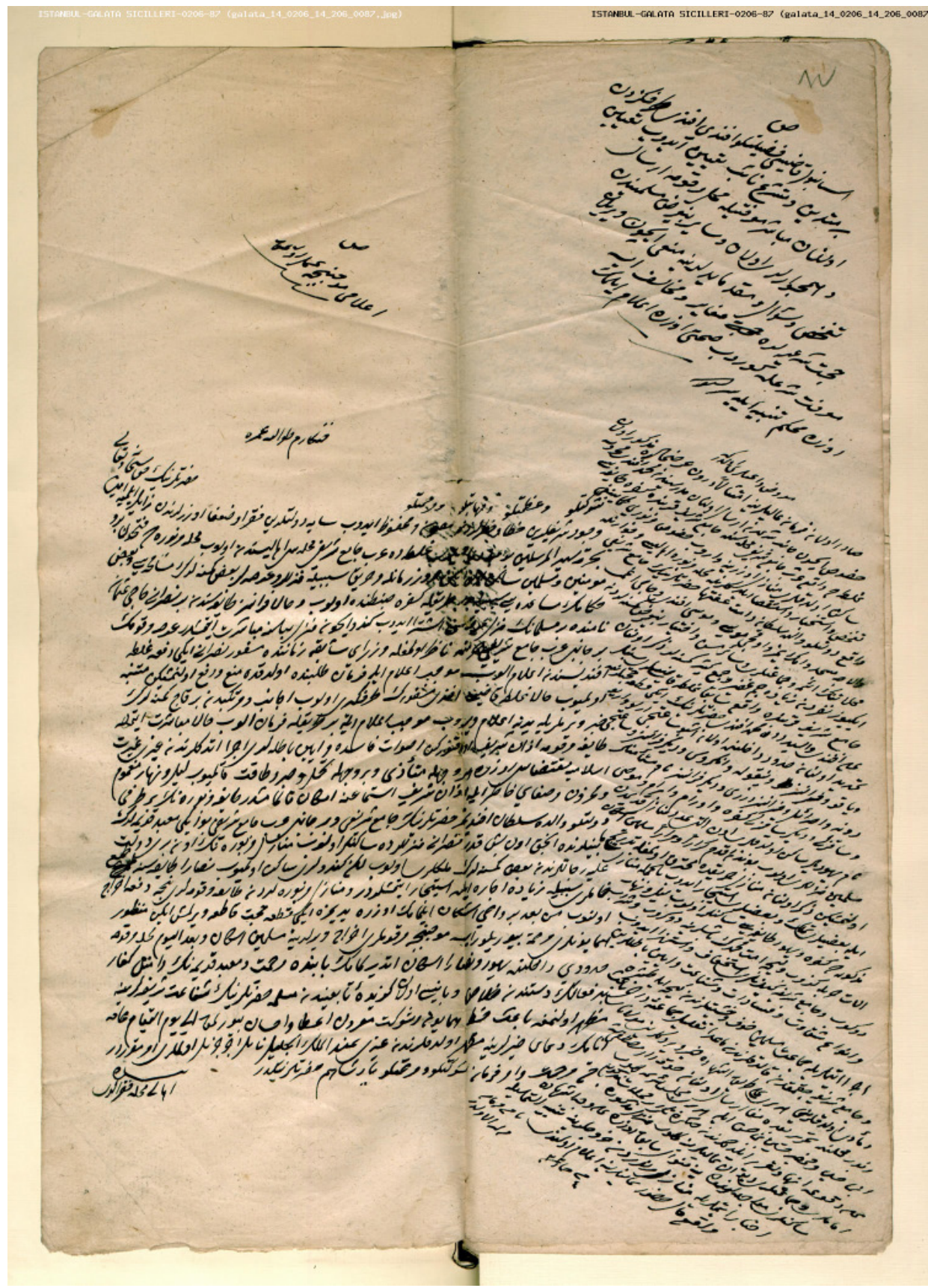


EK-3: Fransız elçisi Pierre Puchot'nun Katolikler lehine divana sunduğu arzıhal. GŞS, 208, 66b (L 1122/Kasım-Aralık 1710)

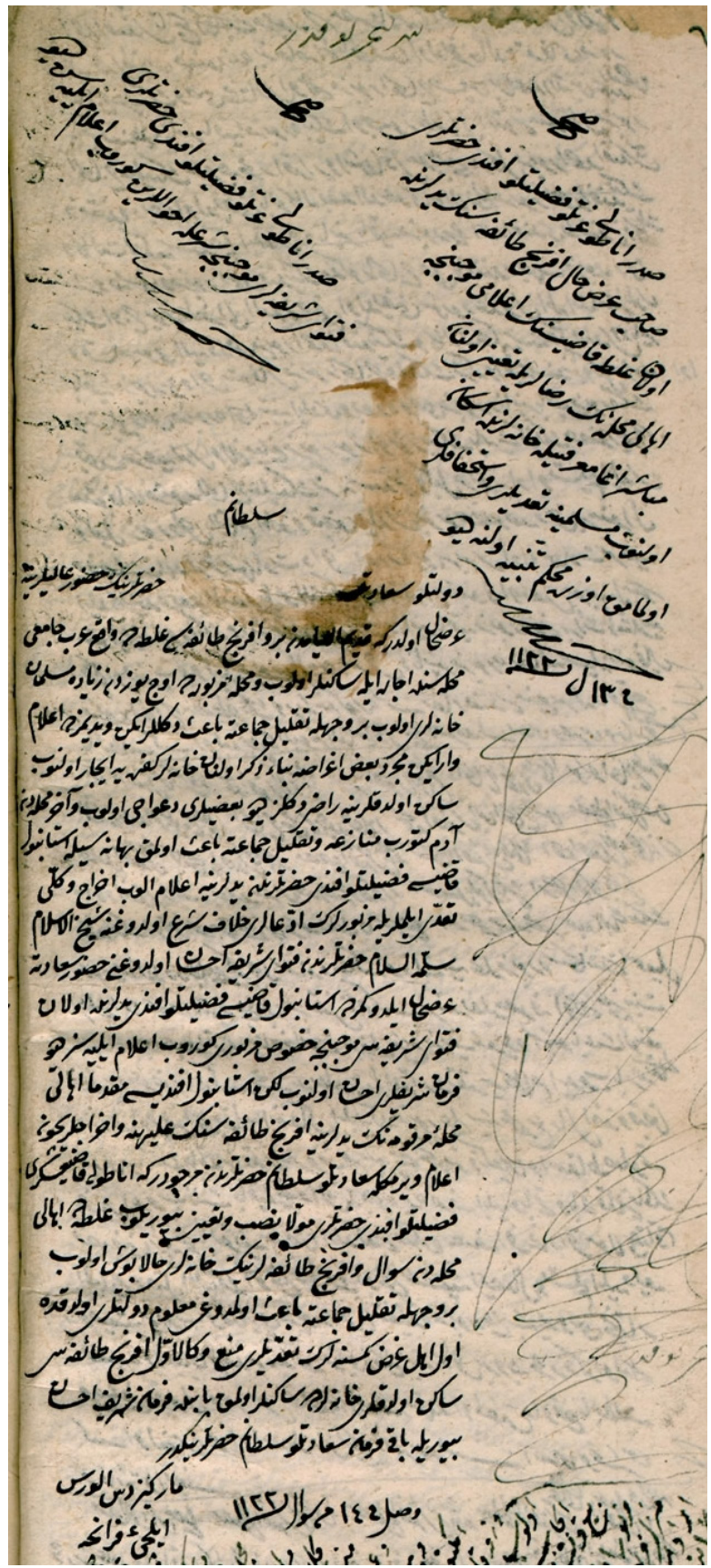


EK-4: Katoliklerin evlerinin yanması üzerine artık Yeni Cami çevresinde oturmaları için bir bahanelerinin kalmadığı ve getirilen oturma yasağı. GŞS, 219, 94b/1 (Z 1124/Ocak 1713)

, 宊

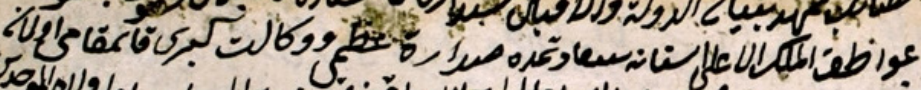

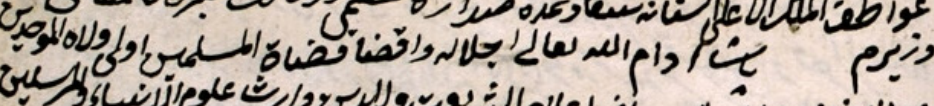

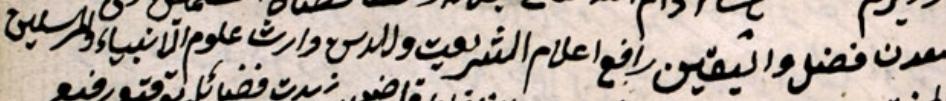

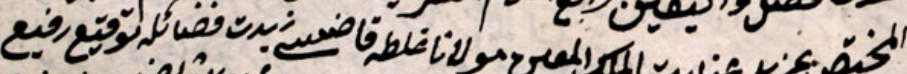
-

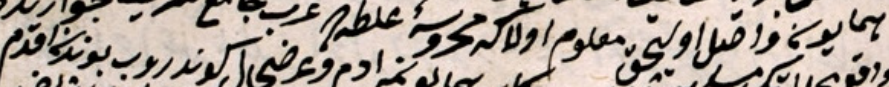

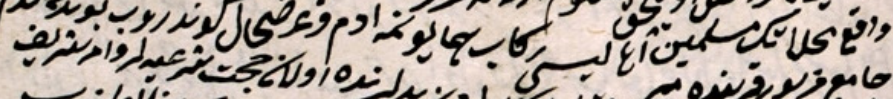
?

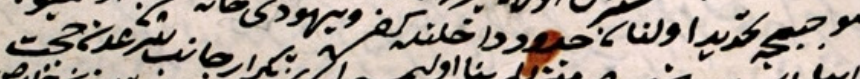
vify Liples is 1

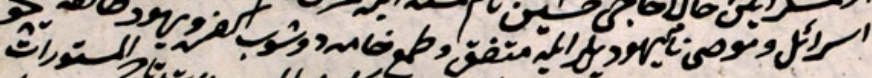

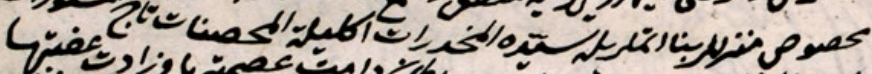
ال م-

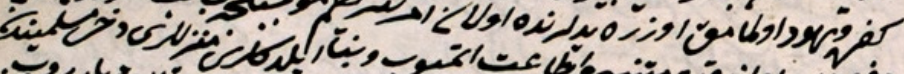

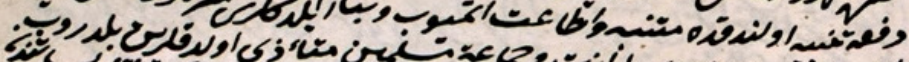

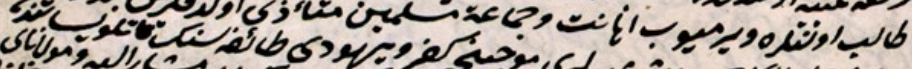

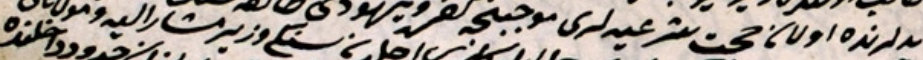

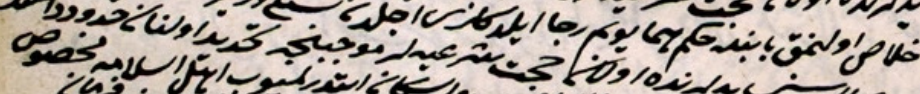

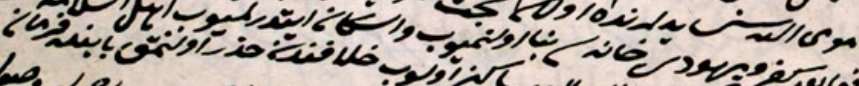
مان

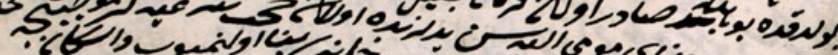
ict

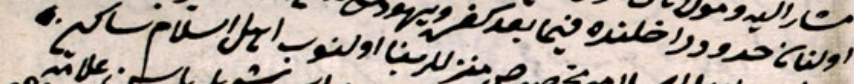

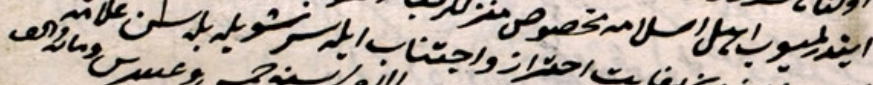

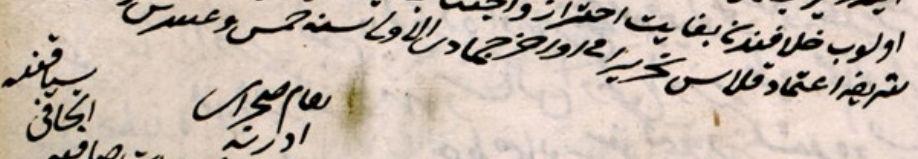


EK-5: Yangın sonrasında gayrimüslimlere getirilen oturma yasağına aykırı davrananların uyarılması. GŞS, 219, 94a/1 (Evh Ca 1125/14-24 Haziran 1713)

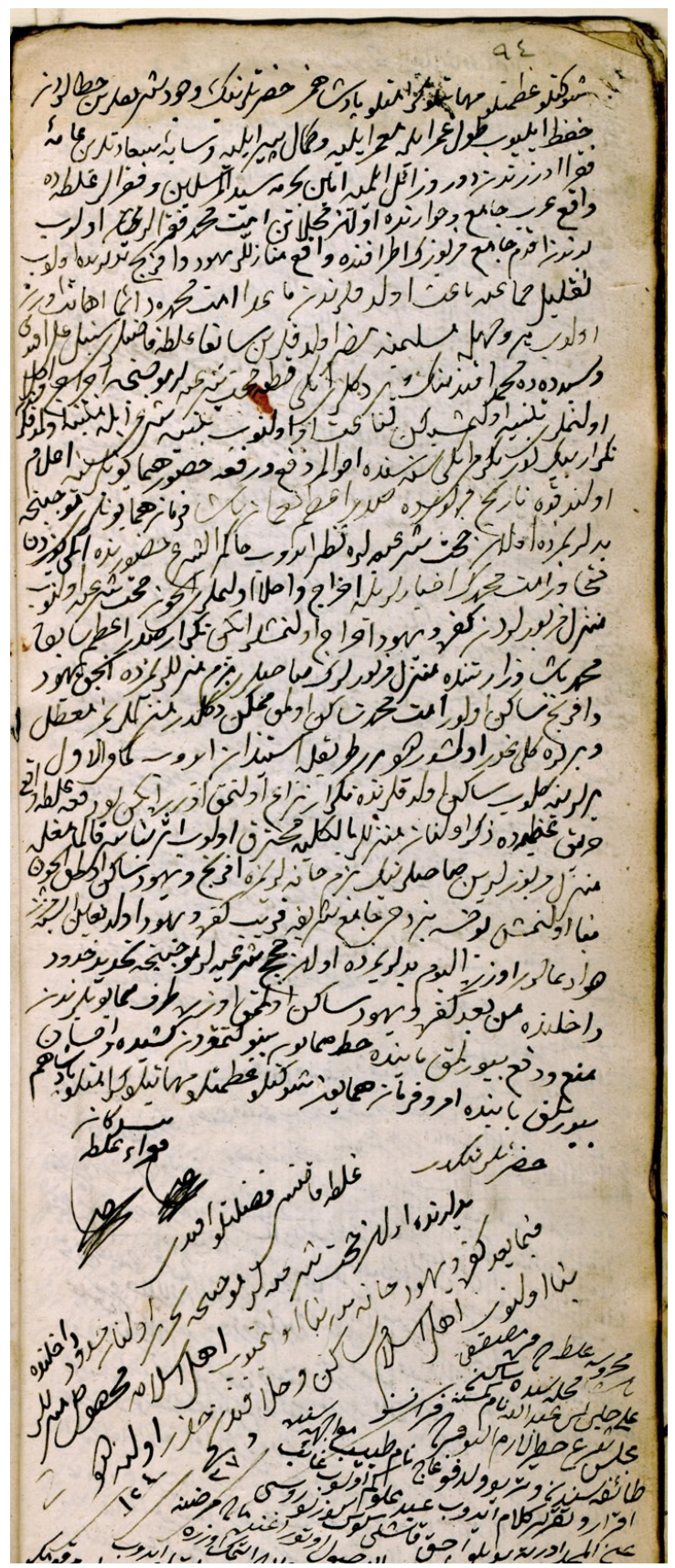


